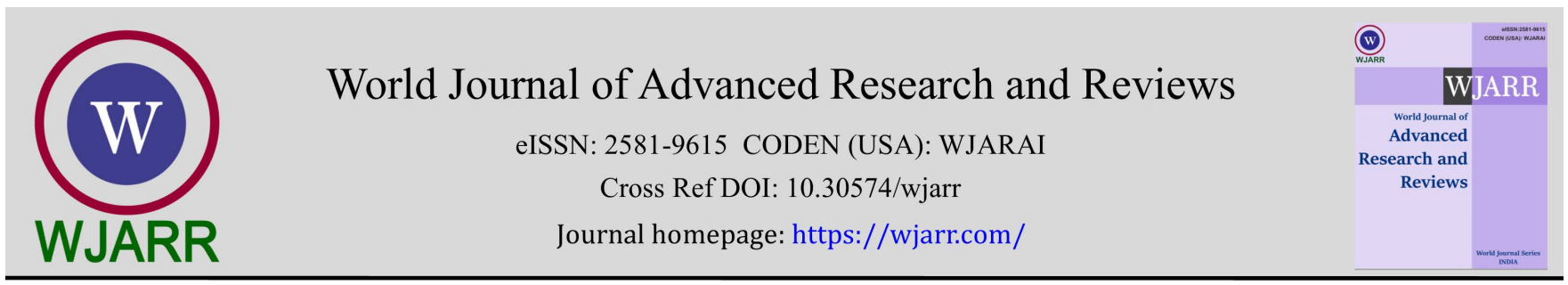

(RESEARCH ARTiClE)

Check for updates

\title{
Inventory, description and analysis of fishing gear and techniques used in Lake Ahémé and its channels, facing the law on fishing in Benin (West-Africa)
}

\author{
Christian Comlan Viaho 1, 3, ${ }^{*}$, Delphine Adandedjan ${ }^{1}$, Simon Ahouansou Montcho ${ }^{2}$, Martin N Gbedey ${ }^{3}$ and \\ Philippe A Laleye 1 \\ ${ }^{1}$ Laboratory of Hydrobiology and Aquaculture, Faculty of Agricultural Sciences, University of Abomey-Calavi, 01 BP: 526 \\ Cotonou, Benin. \\ ${ }^{2}$ Aquaculture and Aquatic Biology and Ecology Research Laboratory, Valley Aquaculture School, National University of \\ Agriculture (UNA), Benin. \\ ${ }^{3}$ Agency for the Integrated Development of the Economic Zone of Lake Ahémé and its Channels (ADELAC). Sègbohouè, \\ Kpomassè, Benin. BP: 01 SEGBOHOUE.
}

World Journal of Advanced Research and Reviews, 2021, 12(01), 401-430

Publication history: Received on 14 September 2021; revised on 23 October 2021; accepted on 25 October 2021

Article DOI: https://doi.org/10.30574/wjarr.2021.12.1.0530

\begin{abstract}
Located in the southwest of Benin, the study environment consists of Lake Ahémé, the Ahô channel, the Tihimey channel, the coastal lagoons of Grand-Popo and Ouidah. The mouth of Avlo-plage makes the area an Estuarine Lagoon environment rich in ichthyofaunal biodiversity where fishing, the main activity of the populations, is practiced with various gears and techniques which are inventoried and described in this study. The methodological approach adopted revolves around documentary research, field surveys through questionnaires and interviews and direct observations. The people interviewed are made up of fishermen; fish wholesalers; agents specializing in fishery production. The study environment was subdivided into 19 observation stations and the data were collected from January 2018 to December 2019. The gears were illustrated by photos and described according to the results of the documentary research and information received from the fishermen. Their variations according to the bodies of water and the stations were calculated using the Excel 2017 table. The drawn meshes of the nets were measured to the nearest millimeter. The study shows that the inventoried fishing gears and techniques include nets, lines, pots, Acadjas and trap dams (Xhas), categorized into 12 gears and 02 techniques, of which $86 \%$ are constant and $14 \%$ are accessories. Gbagbaloulou conical nets dominate the gear while the landing net is the least represented. The smallest mesh measured is $2 \mathrm{~mm}$, while the largest mesh is $25 \mathrm{~mm}$. The fishing gear and techniques used do not ensure rational and sustainable management of fishery resources. Faced with the damage they are causing, the Government proceeded to their systematic removal. Snail farming was initiated to diversify the activities of fishermen.
\end{abstract}

Keywords: Water Bodies; Biodiversity; Acadja; Mosquito net; Sustainable management; Diversification; Ahémé Lake

\section{Introduction}

In old times, fishing was a major source of food for mankind, providing employment and economic benefits to those who practiced it [1]. It was recognized that aquatic resources were a gift of nature of unlimited abundance. But, with the enrichment of knowledge and the dynamic development of the fisheries sector which followed the Second World War, this myth vanished when it was realized that the fishery resources, although renewable, are not infinite and must be properly managed if their contribution to the nutritional, economic and social well-being of a growing world

\footnotetext{
${ }^{*}$ Corresponding author: Christian Comlan Viaho

Laboratory of Hydrobiology and Aquaculture, Faculty of Agricultural Sciences, University of Abomey-Calavi, 01 BP: 526 Cotonou, Benin.
}

Copyright $(2021$ Author(s) retain the copyright of this article. This article is published under the terms of the Creative Commons Attribution Liscense 4.0. 
population is to be maintained [2]. Indeed, fishing makes a fundamental contribution to the food, employment, leisure, commerce and economic well-being of people around the world, whether present or future generations, and should, therefore, be conducted in a responsible manner. The development of fisheries provides for various management measures. These include technical regulations for fishing gear aimed at achieving the general objective of high balanced production in the fishery. These include mesh regulations, for example, intended to improve the selective properties of a fishing gear to reduce by catch of juveniles, the aim being to protect recruitment into larger groups of a stock, especially the spawning stock [3]. In this process of conducting fishing activities responsibly to ensure the sustainability of resources, fishing gear and techniques play an important role; because the quality and quantity of the products caught depend on the gear used for fishing. Fishing gear and techniques are all the means used or implemented by fishermen to catch fish. Many fishing techniques are used by fishermen who choose their fishing gear according to the species they are looking for. Fishing gear is classified into two main families: passive gear and active gear [4]. These two families do not always cohabit easily. Active gear is moved on the bottom or in open water to capture the animals sought; like a butterfly hunt [5]. The passive device does not move, hence its name of "sleeping" device [6]. It is the movement of the fish that leads them to get caught; like a trap. A series of gears are used in inland fishing. Each type of gear has some effect on the aquatic environment [7]. However, if managed with care, they can be used responsibly and sustainably [8].

In the area of Ahémé Lake and its channels, fishing gears and techniques are diversified, including nets, pots and lines. In this document, it will be about making an inventory of fishing gear and techniques used by fishermen, describing them and analyzing their compliance with the current fishing regulations in Benin.

\section{Material and methods}

\subsection{Study area}

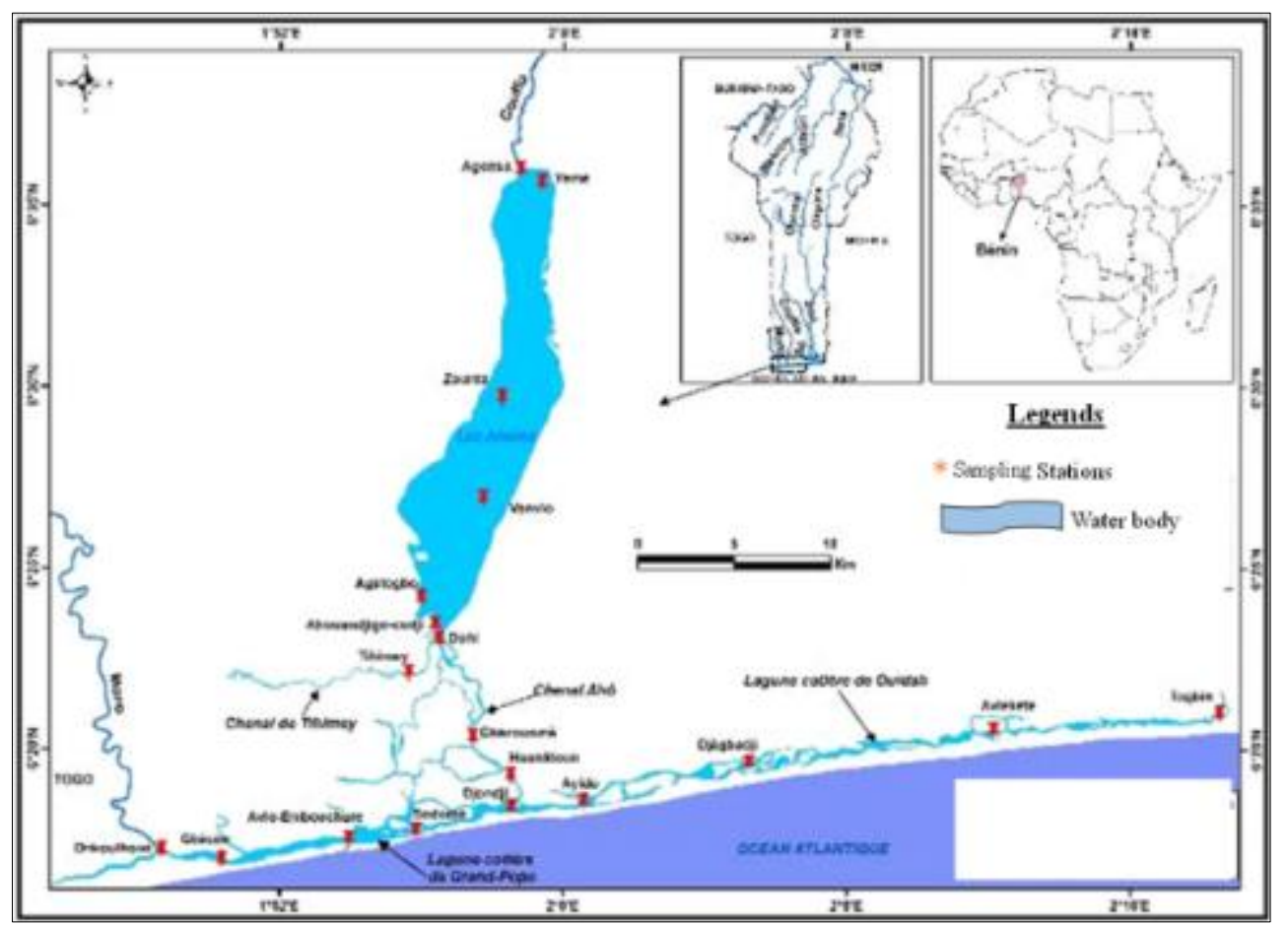

Figure 1 Geographical location and sampling stations of the study area

Figure 1 shows the geographic location of the study area. It is located in the southwest of Benin, in West Africa. It is part of the southwestern wetland of the country, still called the West Complex and classified as "RAMSAR Site 1017" of international importance which embraces the Departments of Mono, Couffo and part of the Department of the Atlantic [9]. With an area of approximately $795 \mathrm{~km}^{2}$ which represents $16.8 \%$ of the coastal zone of Benin, the Couffo RiverAhémé Lake-Ahô Channel-Coastal Lagoons-Mono River complex lies between the meridians $1^{\circ} 51^{\prime}$ 'and $2^{\circ} 05^{\prime}$ of longitude East, and between parallels $6^{\circ} 16^{\prime}$ 'and $6^{\circ} 40^{\prime}$ North latitude (Fig 1). Lake Ahémé serves as a natural boundary between the Mono Department and the Atlantic Department. This research environment is an area favorable to fishing activities [10]. It is an area in which fishing activities are practiced by around $86 \%$ of the working population [11]. It brings together the bodies of water that are: Lake Ahémé (24 km), the Ahô channel (12 km), the coastal lagoon of Grand- 
Popo (20 km), the coastal lagoon of Ouidah ( $40 \mathrm{~km})$ and the canal from Tihimey $(15 \mathrm{~km})$. Together with the Couffo River, this water body forms the RAMSAR 1017 site, of international importance [12]. Lake Ahémé receives the waters of the Couffo River and flows into the Ahô channel and the Tihimey channel. The Ahô channel flows into the coastal lagoons of Grand-Popo and Ouidah at the "water crossroads" of Djondji village [13]. The coastal lagoon of Grand-Popo, receives the waters of the Mono River and flows into the sea through the mouth of "LA BOUCHE DU ROY", in the village of Avlo-Plage. The coastal lagoon of Ouidah, for its part, takes its source from the lagoon of Grand-Popo and the Ahô channel, then finishes its course at the level of the village Togbin, district of Godomey, Municipality of Abomey-Calavi. The presence of the mouth makes the study area an Estuarine Lagoon Environment (ELE) rich in biodiversity where exchanges between the sea and continental waters take place [14]. The main activity of the populations living in the study area is fishing. There are also fish farming, poultry farming, the breeding of small ruminants, the production of food crops and market gardening [15]. The study environment belongs to the subequatorial zone (South Benin) where the rainfall varies from $800 \mathrm{~mm}$ to $1200 \mathrm{~mm}$ per year [16]. It is characterized by the alternation of two rainy seasons (April-July and October-November) and two dry seasons (December-March and August-September).

\subsection{Sampling stations}

A total of nineteen (19) observation stations were selected depending on the direction of water flow and the length of the water bodies (Table 1). They are distributed by water body as follows:

- Ahémé Lake: Agatogbo, Ahouandjigo-Codji, Agonsa, Vonvio, Yèmè and Zounta (06 sampling stations).

- Tihimey Channel: Dohi and Tihimey (02 sampling stations).

- Ahô Channel: Djondji, Gbèzounmè and Hounclou (03 sampling stations).

- Grand-Popo Lagoon: Avlo-Embouchure, Gbêcon, Onkouihoué and Sodomè (04 sampling stations).

- Ouidah Lagoon: Avlékété, Ayido, Djègbadji and Togbin (04 sampling stations).

Table 1 Geographical coordinates of the sampling stations in the study area

\begin{tabular}{|c|c|c|c|c|}
\hline \multirow{2}{*}{ Body of water } & \multicolumn{2}{|c|}{ Geographycal information } & \multirow{2}{*}{ Sampling Station } & \multirow{2}{*}{$\begin{array}{c}\text { Station } \\
\text { codes }\end{array}$} \\
\hline & $\mathbf{X}$ & $\mathbf{Y}$ & & \\
\hline \multirow{6}{*}{ Ahémé Lake } & $06^{\circ} 35^{\prime} 59,1^{\prime \prime} \mathrm{N}$ & $001^{\circ} 58 ' 47,1^{\prime \prime} \mathrm{E}$ & Agonsa & LA1 \\
\hline & $06^{\circ} 35^{\prime} 37,2^{\prime \prime} \mathrm{N}$ & $001^{\circ} 59^{\prime} 23,8 " \mathrm{E}$ & Yemè & LA2 \\
\hline & $06^{\circ} 29^{\prime} 42,0^{\prime \prime} \mathrm{N}$ & $001^{\circ} 58^{\prime} 16,5^{\prime \prime} \mathrm{E}$ & Zounta & LA3 \\
\hline & $06^{\circ} 26^{\prime} 54,7^{\prime \prime} \mathrm{N}$ & $001^{\circ} 57^{\prime} 44,7^{\prime \prime} \mathrm{E}$ & Vonvio & LA4 \\
\hline & $06^{\circ} 24^{\prime} 09,4^{\prime \prime} \mathrm{N}$ & $001^{\circ} 56^{\prime} 00,8^{\prime \prime} \mathrm{E}$ & Agatogbo & LA5 \\
\hline & $06^{\circ} 23^{\prime} 24,5^{\prime \prime} \mathrm{N}$ & $001^{\circ} 56^{\prime} 23,3^{\prime \prime} \mathrm{E}$ & Ahouandjigo-codji & LA6 \\
\hline \multirow[b]{2}{*}{$\begin{array}{l}\text { Tihimey } \\
\text { Channel }\end{array}$} & $06^{\circ} 22^{\prime} 59,8^{\prime \prime} \mathrm{N}$ & $001^{\circ} 56^{\prime} 30,1^{\prime \prime} \mathrm{E}$ & Dohi & CT1 \\
\hline & $06^{\circ} 22^{\prime} 05,7^{\prime \prime} \mathrm{N}$ & $001^{\circ} 55^{\prime} 39,2^{\prime \prime} \mathrm{E}$ & Tihimey & CT2 \\
\hline \multirow{3}{*}{ Ahô Channel } & $06^{\circ} 20^{\prime} 18,8^{\prime \prime} \mathrm{N}$ & $001^{\circ} 57^{\prime} 27,7^{\prime \prime} \mathrm{E}$ & Gbêzounmè & $\mathrm{AH} 1$ \\
\hline & $06^{\circ} 19^{\prime} 16,7^{\prime \prime} \mathrm{N}$ & $001^{\circ} 58^{\prime} 31,8^{\prime \prime} \mathrm{E}$ & Hounklou & $\mathrm{AH} 2$ \\
\hline & $06^{\circ} 18^{\prime} 22,5^{\prime \prime} \mathrm{N}$ & $001^{\circ} 58^{\prime} 33,5^{\prime \prime} \mathrm{E}$ & Djondji & AH3 \\
\hline \multirow{4}{*}{$\begin{array}{l}\text { Ouidah } \\
\text { Lagoon }\end{array}$} & $06^{\circ} 20^{\prime} 58,4^{\prime \prime} \mathrm{N}$ & $002^{\circ} 18^{\prime} 31,5^{\prime \prime} \mathrm{E}$ & Togbin & L01 \\
\hline & $06^{\circ} 20^{\prime} 31,9^{\prime \prime} \mathrm{N}$ & $002^{\circ} 12^{\prime} 09,1^{\prime \prime} \mathrm{E}$ & Avlékété & $\mathrm{LO} 2$ \\
\hline & $06^{\circ} 19^{\prime} 36,1^{\prime \prime} \mathrm{N}$ & $002^{\circ} 05^{\prime} 14,8 " \mathrm{E}$ & Djègbadji & LO3 \\
\hline & $06^{\circ} 18^{\prime} 32,4^{\prime \prime} \mathrm{N}$ & $002^{\circ} 00^{\prime} 35,8 " \mathrm{E}$ & Ayido & $\mathrm{LO} 4$ \\
\hline \multirow{4}{*}{$\begin{array}{l}\text { Grand-Popo } \\
\text { Lagoon }\end{array}$} & $06^{\circ} 17^{\prime} 44,2^{\prime \prime} \mathrm{N}$ & $001^{\circ} 55^{\prime} 52,3 " \mathrm{E}$ & Sodomè & LG1 \\
\hline & $06^{\circ} 17^{\prime} 30,1^{\prime \prime} \mathrm{N}$ & $001^{\circ} 53^{\prime} 58,7^{\prime \prime} \mathrm{E}$ & Avlo-Embouchure & LG2 \\
\hline & $06^{\circ} 16^{\prime} 55,3^{\prime \prime} \mathrm{N}$ & $001^{\circ} 50^{\prime} 22,8^{\prime \prime} \mathrm{E}$ & Gbècon & LG3 \\
\hline & $06^{\circ} 17^{\prime} 12,4^{\prime \prime} \mathrm{N}$ & $001^{\circ} 48^{\prime} 41,4^{\prime \prime} \mathrm{E}$ & Onkouihoué & LG4 \\
\hline
\end{tabular}




\subsection{Inventory and description of fishing gear and techniques}

The methodological approach adopted revolves around documentary research, field surveys through questionnaires and interviews and direct observations. The data were collected at the level of the 19 stations from January 2018 to December 2019. The people interviewed consist of fishermen; fish wholesalers; agents specializing in fishery production (resource persons); and local elected officials. Population statistics (RGPH-4, 2013) available at the level of each Municipality were used [17]. The gear was illustrated by pictures and described according to the information received from the wise and notable of the fishing villages. They were then categorized according to their mode of action into passive method gear and active method gear [18]. An active method gear is characterized by the displacement or movement of the gear that comes into contact with the fish to catch it. On the other hand, a passive method gear is characterized by the movement of the fish which is attracted by a bait or not, in order to be caught; in this case, the apparatus or technique used is sedentary. The fish, in its movement, is caught by the gear. The drawn meshes of the nets were measured to the nearest millimeter, using a graduated measuring cup. These meshes were compared with the provisions contained in the framework law on fisheries and aquaculture in force in the Republic of Benin. The frequency of the gears was determined with the occurrence calculation of these gears. The percentage of occurrence (C) made it possible to obtain the consistency of a device in a given environment. It is the ratio expressed as a percentage between the number of samples (p) where the device i appears and the total number of samples (P) of the considered unit [19]. It is obtained according to the formula:

$$
\mathrm{C}=\frac{\mathrm{px} 100}{\mathrm{P}}
$$

The value of $C$ makes it possible to distinguish four groups of gear [19]:

- constant gear $(\mathrm{C} \geq 50 \%)$;

- accessory gear $(25 \% \leq \mathrm{C}<50 \%)$;

- accidentel gear $(5 \% \mathrm{C}<25 \%)$;

- $\quad$ rare gear $(\mathrm{C}<5 \%)$.

The occupation of water bodies by sedentary fishing techniques (Acadjas and xhas) was obtained using satellite images with ArcView 3.2 software; it was also used for the production of geographic and thematic situation maps. The variations in fishing gear and techniques by body of water and by station were calculated using the 2017 Excel table. The list of fish species caught by each fishing gear and technique was presented according to the CLOFFA standard ( Check-List of the Freshwater Fishes of Africa) [20; 21]. The data collected was processed using appropriate software such as 2017 Word for entering the document; calculated using the 2017 Excel table for producing tables and graphs [22].

\section{Results}

\subsection{Inventoried fishing gear and techniques}

Table 2 shows the list of fishing gears and techniques inventoried during the study period. In total, 12 fishing gears and 02 fishing techniques are inventoried, including nets, lines, pots, acadjas and trap dams (xhas).The devices listed are:

- The nets: Gbagbaloulou net (FG), Mesh net (FM), Hawk net (FE), Ethion net (ET), Mindokpo-Konou net (FK), Net landing net (EF) and Mosquito nets (MQ).

- $\quad$ Lines: Baited Hook Longline (PA), Unbaited Hook Longline (PN) and Line and Rod Fishing (PL) lines.

- The pots: the bamboos (BA) and the Cages (NA).

- The techniques encountered are: acadjas (AC) and xhas trap dams (BN). 
Table 2 List of fishing gear and techniques inventoried in Ahémé Lake and its channels by station and by body of water

\begin{tabular}{|c|c|c|c|c|c|c|c|c|c|c|c|c|c|c|c|c|c|c|c|c|}
\hline \multirow{2}{*}{$\begin{array}{c}\text { Gear } \\
\text { fishing } \\
\text { and } \\
\text { tech. }\end{array}$} & \multicolumn{6}{|c|}{ Ahémé Lake } & \multicolumn{2}{|c|}{$\begin{array}{l}\text { Tihimey } \\
\text { Channel }\end{array}$} & \multicolumn{3}{|c|}{ Ahô Channel } & \multicolumn{4}{|c|}{ Ouidah Lagoon } & \multicolumn{4}{|c|}{$\begin{array}{c}\text { Grand-Popo } \\
\text { Lagoon }\end{array}$} & \multirow{2}{*}{$\begin{array}{c}\text { Tota } \\
1\end{array}$} \\
\hline & $\begin{array}{c}\text { LA } \\
1\end{array}$ & $\begin{array}{c}\text { LA } \\
2\end{array}$ & $\begin{array}{c}\text { LA } \\
3\end{array}$ & $\begin{array}{c}\text { LA } \\
4\end{array}$ & $\begin{array}{c}\text { LA } \\
5\end{array}$ & $\begin{array}{c}\text { LA } \\
6\end{array}$ & $\begin{array}{c}\text { CT } \\
1\end{array}$ & $\begin{array}{l}\text { CT } \\
2\end{array}$ & $\begin{array}{c}\text { CA } \\
1\end{array}$ & $\begin{array}{c}\text { CA } \\
2\end{array}$ & $\begin{array}{c}\text { CA } \\
3\end{array}$ & $\begin{array}{c}\text { LO } \\
1\end{array}$ & $\begin{array}{c}\text { LO } \\
2\end{array}$ & $\begin{array}{c}\text { LO } \\
3\end{array}$ & $\begin{array}{c}\text { LO } \\
4\end{array}$ & $\begin{array}{c}\text { LG } \\
1\end{array}$ & $\begin{array}{c}\text { LG } \\
2\end{array}$ & $\begin{array}{c}\text { LG } \\
3\end{array}$ & $\begin{array}{c}\text { LG } \\
4\end{array}$ & \\
\hline FG & 1 & 1 & 1 & 1 & 1 & 1 & 1 & 1 & 1 & 1 & 1 & 1 & 1 & 1 & 1 & 1 & 1 & 0 & 0 & 17 \\
\hline FM & 1 & 1 & 1 & 1 & 1 & 1 & 1 & 1 & 1 & 1 & 1 & 1 & 1 & 1 & 1 & 1 & 1 & 1 & 1 & 19 \\
\hline FK & 1 & 1 & 1 & 1 & 1 & 1 & 1 & 1 & 1 & 1 & 1 & 1 & 1 & 1 & 1 & 1 & 1 & 0 & 0 & 17 \\
\hline MQ & 1 & 1 & 1 & 1 & 1 & 1 & 1 & 1 & 1 & 1 & 1 & 1 & 1 & 1 & 1 & 0 & 0 & 0 & 0 & 15 \\
\hline $\mathrm{FE}$ & 1 & 1 & 1 & 1 & 1 & 1 & 1 & 1 & 1 & 1 & 1 & 1 & 1 & 1 & 1 & 1 & 1 & 1 & 1 & 19 \\
\hline ET & 1 & 1 & 1 & 1 & 1 & 1 & 1 & 1 & 1 & 1 & 1 & 1 & 1 & 1 & 1 & 1 & 1 & 0 & 0 & 17 \\
\hline $\mathrm{EF}$ & 1 & 0 & 0 & 0 & 0 & 0 & 0 & 0 & 0 & 0 & 0 & 0 & 0 & 0 & 0 & 0 & 0 & 0 & 0 & 1 \\
\hline PA & 1 & 1 & 1 & 1 & 1 & 1 & 1 & 1 & 1 & 1 & 1 & 1 & 1 & 1 & 1 & 1 & 1 & 1 & 1 & 19 \\
\hline PN & 1 & 1 & 1 & 1 & 1 & 1 & 1 & 1 & 1 & 1 & 1 & 1 & 1 & 1 & 1 & 1 & 1 & 1 & 1 & 19 \\
\hline PL & 1 & 1 & 1 & 1 & 1 & 1 & 1 & 1 & 1 & 1 & 1 & 1 & 1 & 1 & 1 & 1 & 1 & 1 & 1 & 19 \\
\hline BA & 0 & 0 & 0 & 1 & 1 & 0 & 0 & 0 & 0 & 0 & 0 & 0 & 0 & 0 & 0 & 0 & 0 & 0 & 0 & 2 \\
\hline NA & 1 & 1 & 1 & 1 & 1 & 1 & 1 & 1 & 1 & 1 & 1 & 1 & 1 & 1 & 1 & 0 & 0 & 1 & 0 & 16 \\
\hline $\mathrm{AC}$ & 1 & 1 & 1 & 1 & 1 & 1 & 1 & 1 & 1 & 1 & 1 & 1 & 1 & 1 & 1 & 0 & 0 & 0 & 0 & 15 \\
\hline BN & 0 & 0 & 0 & 0 & 1 & 1 & 1 & 1 & 1 & 1 & 1 & 1 & 1 & 1 & 1 & 0 & 0 & 0 & 0 & 11 \\
\hline TOTAL & 12 & 11 & 11 & 12 & 13 & 12 & 12 & 12 & 12 & 12 & 12 & 12 & 12 & 12 & 12 & 8 & 8 & 6 & 5 & \\
\hline
\end{tabular}

Legend: FG = Net Gbagbaloulou; FM = Mesh Net; FK = MindokpoKonou Net; MQ = Mosquito net; FE = Hawk Net; ET = Ethion Net; EF = Net Landing Net, PA = Baited Hook Long line; PN = Non Baited Hook Long Line: PL = Line and rod fishing; BA = Bamboo Fishing; NA = Catch Fishing; AC = Acadja; $\mathrm{BN}=$ Dam at Catch Fishing (Xhas); $1=$ Presence; $0=$ Absence.

\subsection{Description of fishing gear and techniques}

\subsubsection{Cast net}

The hawk is a fishing net made up of a rope, a cap (the net itself), a lead rope and a peripheral basal pocket (fig. 2 and 3 ). It has a conical shape and variable height. Launched, it spreads out by centrifugal force and captures all living beings covered. It is practiced in deep areas and by two fishermen in a canoe, the first of which throws the net and the second leads the canoe (fig 2). There are four (4) variants of the use of this net, namely:

- $\quad$ The "Safo" cast net: fitted with a catch pocket materialized by hems. It can be launched from a canoe and pulled towards you;

- $\quad$ The "Kotchokoun" cast net: smaller in size, often used in areas reduced to rising water levels;

- The cast net "Djétowlé" is launched into the water and is not equipped with a rope or a jet, let alone a catch pocket. It is used by a fisherman with or without a canoe who, after casting the net, jumps into the water to catch the fish.;

- The "Fodoè" cast net: the same characteristic as the previous ones, it is smaller in size and is used by a fisherman who walks on foot in the body of water to practice fishing. It does not require a canoe for its use.

The average yield of a cast net is 0.5 - $3 \mathrm{~kg}$ per day [13]. 


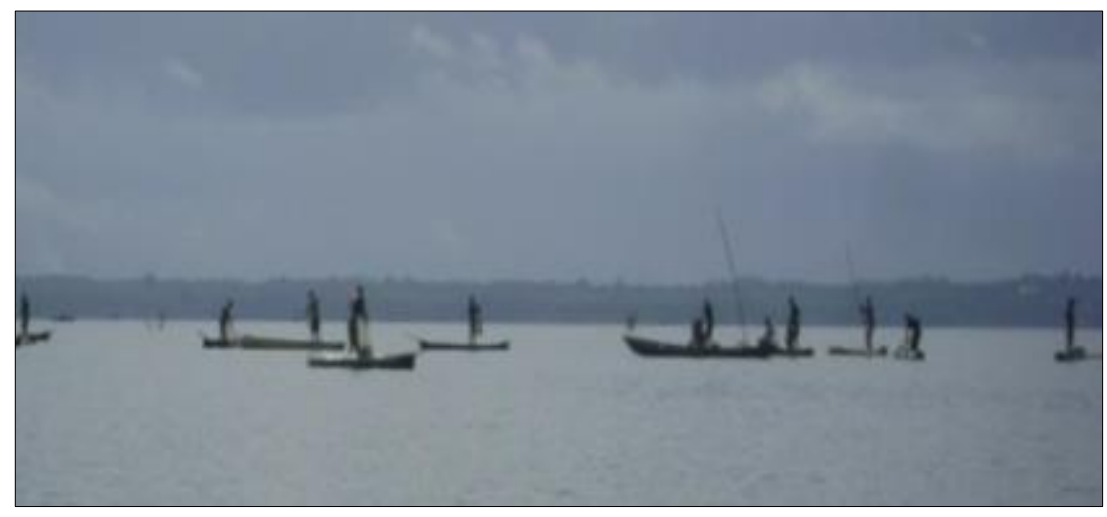

Figure 2 Fishermen using the cast net on Lake Ahémé

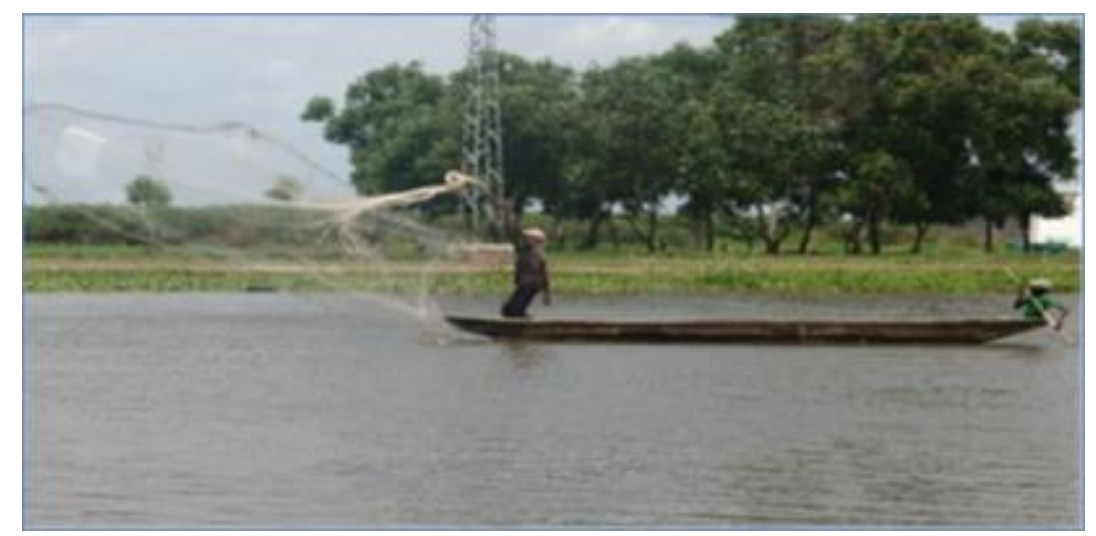

Figure 3 Fishermen using the cast net on Grand-Popo lagoon

\subsection{2. "Ethion" trailing net}

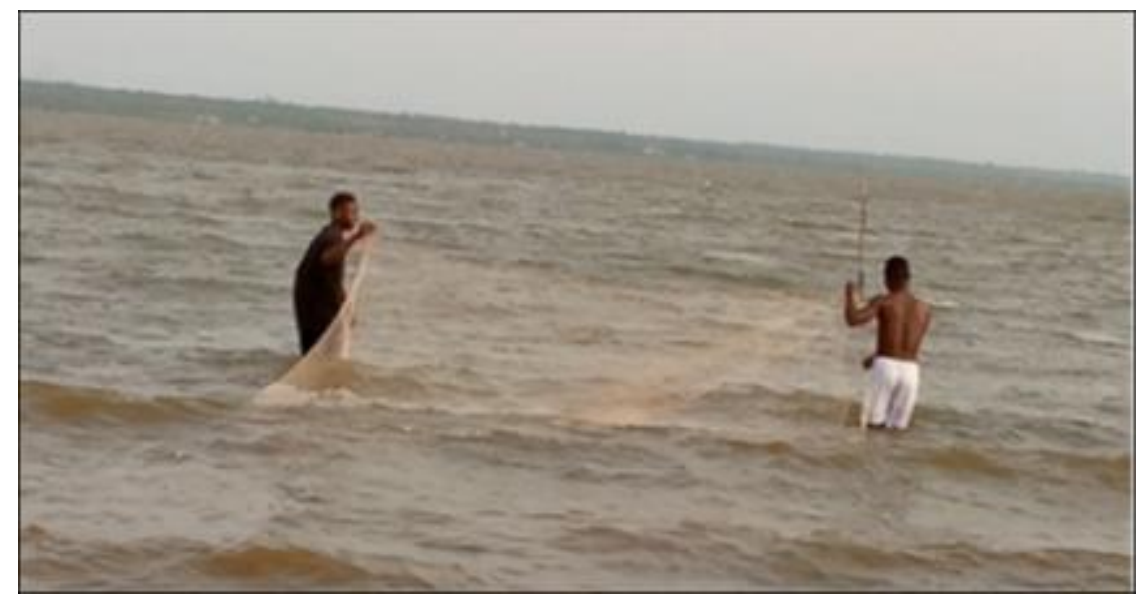

Figure 4 Ethion fishing net dragged by two fishermen in Lake Ahémé in Bopa-Dado village

Called in the local language MINAGBE "Bôludô", which means shrimp net, "Ethion" is a pocket net or conical basket with a rectangular opening mounted on wooden poles which serve as curved handles. Usually, "Ethion" does not carry any sinkers at its base; which makes it possible to scrape the bottom, the upper edge being provided with floats. The top of the cone is open and provided with a string that allows it to be tied with the pole. It forms a slide which makes it easy to collect fish, shrimps and crabs accumulated at the bottom of the pocket. "Ethion" is made with layers of nets of variable mesh. The mesh gets finer and finer from the opening to the top of the cone. They generally vary from $2 \mathrm{~mm}$ to 
$25 \mathrm{~mm}$. When the pouch is made with mosquito net, the "Ethion" is called "Mandovi". The "Ethion" net is dragged at night in shallow areas and sometimes near the grass by two fishermen each holding a sleeve and catching everything in its path (fig 4). This machine is very widespread in the villages of the fishermen. 30 to 40 minutes after the net has been dragged, the two fishermen lift it to recover the catch. Fishing at "Ethion" is a fairly tough fishery because the fishermen spend a good part of the night (between 10 p.m. and 3 a.m. for some, 11 p.m. and 6 a.m. for others) immersed in the water. The catches of this net consist of shrimps, crabs, and species of the family Clupeidae, cichlids etc. In the environment of Ahémé Lake, the net belongs in most cases to the fishmongers. A fishmonger can have up to nine (09) Ethions. Ethion fishermen collect this net from them, with a commitment to bring back the entire catch to sell at a relatively low price to the owner fishmonger. Generally, the fishermen take part of the catch before the sale and in front of the fishmonger for self-consumption with the family. The average yield of an Ethion net is 2.5 - $10 \mathrm{~kg}$ per day in the study area [13].

\subsubsection{Landing net}

The landing net is a fishing gear introduced in Ahémé Lake in 2018. It consists of a handle and a wooden hoop. The sleeve is $2 \mathrm{~m}$ in length and the hoop $2.5 \mathrm{~m}$ in diameter. The pocket of the net is $1 \mathrm{~m}$ deep (fig 5). It is used exclusively to the north of Lake Ahémé by fishermen from the village of Agonsa, Arrondissement of Bopa-Center, Municipality of Bopa. He is dragged by two fishermen, one holding the sleeve and the other part of the hoop. It is a device whose nets are fine mesh, illegal and prohibited. The average yield of a landing net is 1.5 - $8 \mathrm{~kg}$ per day in the study area [13].

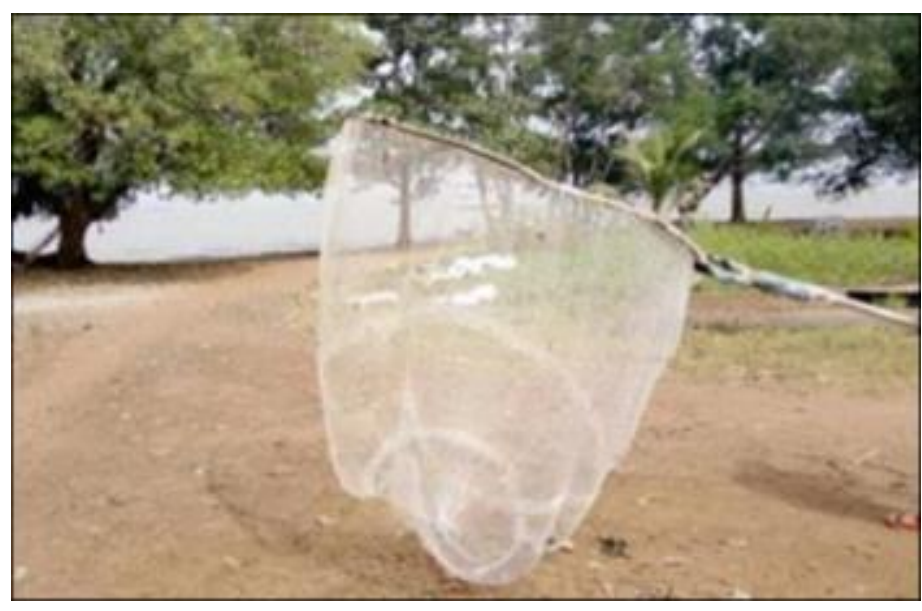

Figure 5 Landing net used in Lake Ahémé

\subsubsection{Gill net}
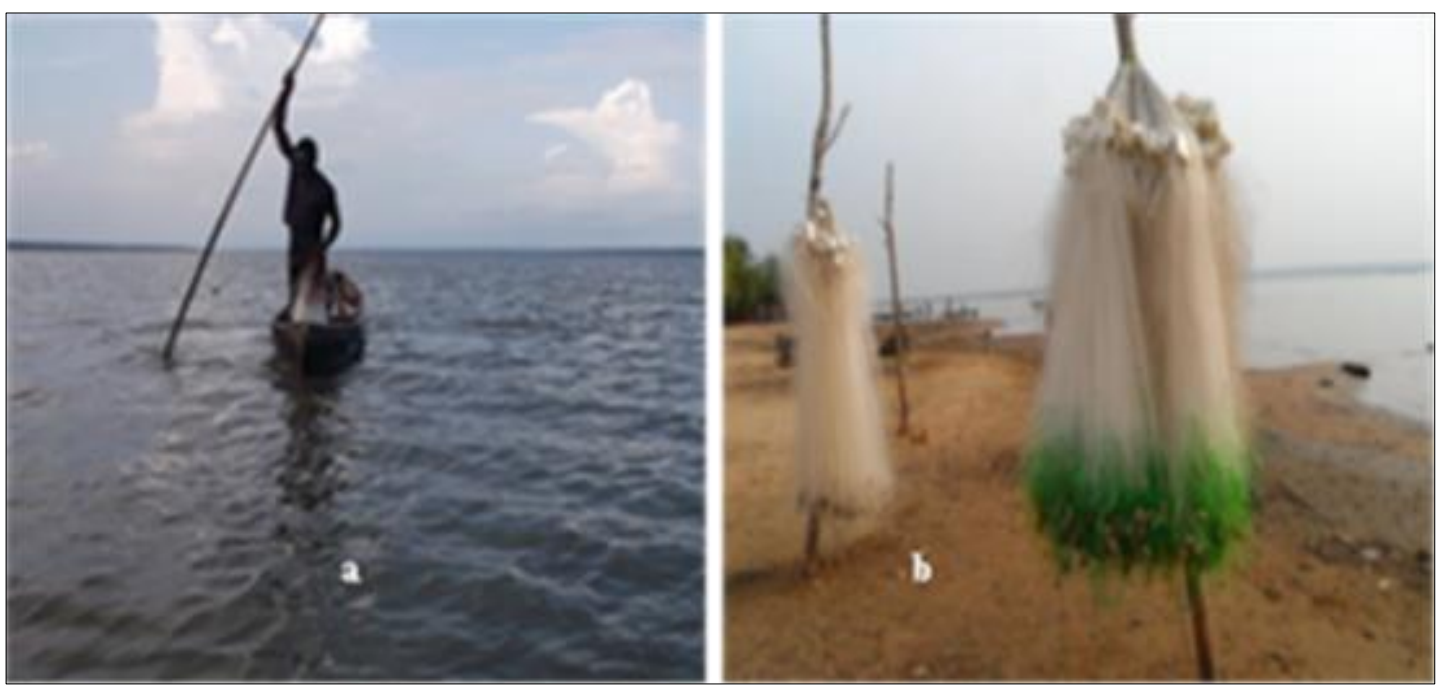

Figure 6 a) Fisherman setting the gill net; b) Gill net hung on the poles after fishing 
Also called "Tohounga" in the local MINAGBE language, the gill net consists of a rectangular net sheet of variable size. It is attached to two stakes which are usually shrub poles driven into the bottom. The headline is fitted with floats (made of synthetic foams) and the bottom line is weighted to keep the net deployed between the surface of the water and the bottom, so that the headline does not emerge. The average length of the "Tohounga" gillnet on Lake Ahémé is about 40 $\mathrm{m}$; its drop is $1 \mathrm{~m}$ to $1.50 \mathrm{~m}$ depending on the depths (fig 6). The spacing between the weights for this net varies from $0.5 \mathrm{~m}$ to $1.50 \mathrm{~m}$. Usually, the "Tohounga" net is set in the water in the evening and picked up early the next day. It is found in all bodies of water in the study area. It allows to capture pelagic species and sometimes crabs and shrimps. When its mesh size is less than $20 \mathrm{~mm}$, it becomes a prohibited gear, whatever the target species, according to the regulations in force in inland fishing in Benin. The average yield of a gill net is 1.5 - $15 \mathrm{~kg}$ per day in the study area [13].

\subsubsection{Mosquito net}

The mosquito net is nothing other than the mosquito net used to catch fish. It is dragged by two fishermen who overturn the mosquito net so as to have a pocket of concentration of fish (fig 7). It is used in shallow areas. It is a piece of gear that was introduced into Lake Ahémé and its channels in 2015 by fishing fishermen for Acadja from the Lake Nokoué area. The average yield of a mosquito net is 5.5 - $30 \mathrm{~kg}$ per day in the study area [13].

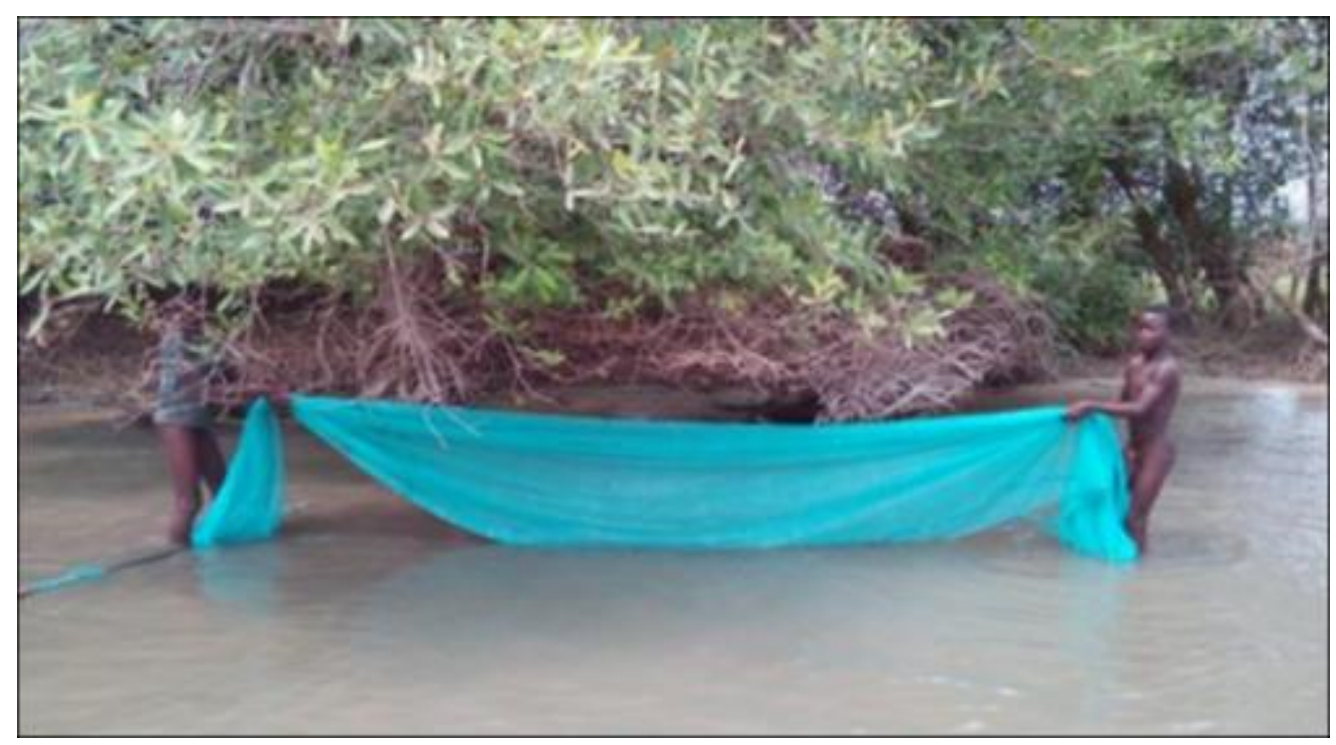

Figure 7 Mosquito net used by two fishermen in the lagoon of Ouidah

\subsection{6. "Mindokpokonou" net}

"Mindokpokonou", literally " one person to rejoice, to be happy " in other words, " joy for one person ", is a fishing gear made with the mosquito nets sewn next to each other to form a long tablecloth (fig 8). It takes about 35 to 45 mosquito nets of two places disjointed in the longitudinal direction to form a Mindokpokonou net. When laying, it is arranged in a polygonal shape and supported by stakes, with a long arm that acts as a barrier for the fish. These, in their movement, come up against this arm, look for an exit, and find themselves directly inside the gear. When raising the net, the fisherman starts with the long arm and concentrates the fish in the pocket of the gear to catch them. It is a devastating device which not only captures fish species of all sizes (eggs, larvae, fry, fingerlings and fish), but creates turbidity in the water in the exploitation areas, causing the death of fish by asphyxiation. The use of this gear has negative consequences on resources, the aquatic ecosystem and the health of populations. Indeed, these mosquito nets are intended for the protection and the fight against malaria in these humid environments very favorable to the development of the mosquitoes responsible for this disease. It is a piece of gear that was introduced into Lake Ahémé and its channels in 2015 by fishing fishermen for Acadja from the Lake Nokoué area. The average yield of this fishing gear is 10 - $60 \mathrm{~kg}$ per day in the study area [13]. 


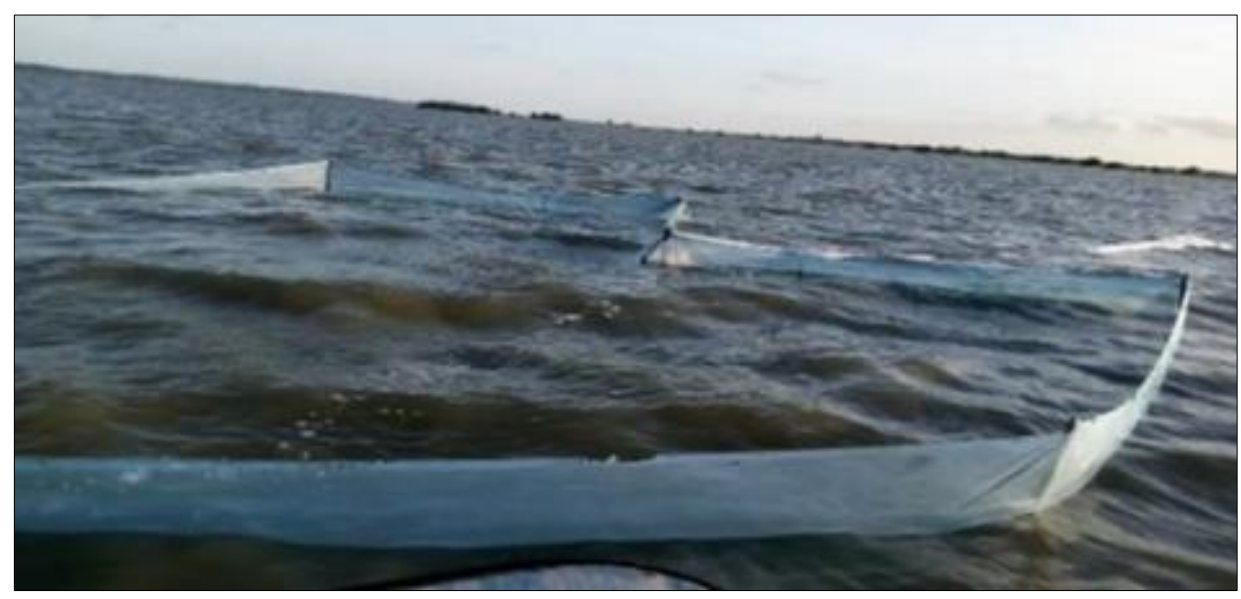

Figure 8 MindokpoKonou net used in Lake Ahémé

\subsection{7. "Gbagbaloulou" conical net}

The Gbagbaloulou fishing gear is a net mounted in the form of a trawl (fig 9) $10 \mathrm{~m}$ on average long with a mesh of about $10 \mathrm{~mm}$, (stretched mesh) supported inside by wooden hoops or pipe concrete and a device consisting of a small net similar to that of the traps, the constriction of which prevents the fish from leaving. It is a conical-shaped gear that was introduced in 1983 into the waters of Lake Ahémé and its channels, by fishermen who returned from Côte d'Ivoire where the gear is widely used [14]. It has a tie rope at its lower end and two pegs at the opening that act as handles. The capture technique consists of placing the net at the bottom in the substrate. It captures Gobiidae (Porogobius sp.), Clupeidae, Gerridae, Paralichthyidae (Citharichthys stampflii), Ophichthyidae (Dalophis sp.). This gear is prohibited from use because of its narrow mesh and the fact that it prevents the migration of fish. Several units of Gbagbaloulous nets are installed end to end so as to form a barrier over several tens of meters. The water flow velocity is reduced at these levels. The speed of the water and its depth are very determining for the effectiveness of this machine. This may explain why its use is limited to shallow areas where the current is less strong. When laying, the opening is directed towards the sea at high tide, and towards the East or the North at low tide, depending on whether the fisherman is in the areas of the channels, lagoons or in Lake Ahémé. The average yield of a Gbagbaloulou net is 1.5 - $10 \mathrm{~kg}$ per day in the study area [13].

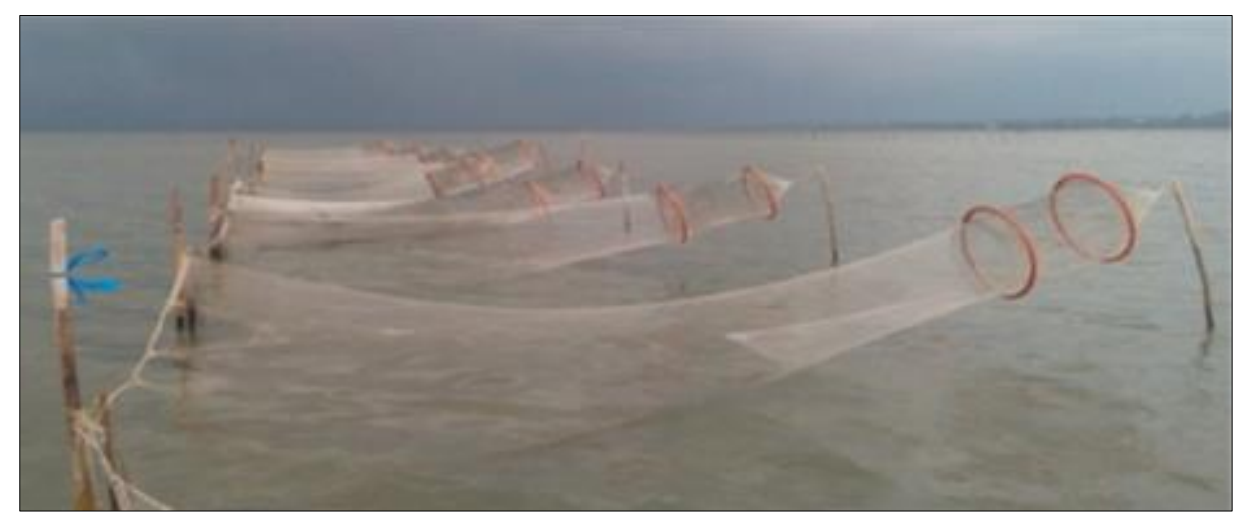

Figure 9 Gbagbaloulou net used in Ahémé Lake

\subsubsection{Baited hook long line "Djohoun"}

The baited hook long line consists of a main line with hooks to which branch lines are attached at and $1.5 \mathrm{~m}$ to $2 \mathrm{~m}$ apart [20]. The branch lines are fitted with baited hooks. The baits consist of viscera and / or uneaten fresh fish scraps, worms ... Both ends of the long line are supported by poles, to which identification flags are attached (fig 10). This gear does not represent any danger, neither for the fauna, nor for the fishermen. When setting, the fisherman, equipped with a canoe, starts from a stake to extend the hook line. Given the length of the line, a marker is placed every $50 \mathrm{~m}$ to ensure proper operation of the machine. The fish gets caught trying to eat the bait. The average yield of a $100 \mathrm{~m}$ baited hook long line is 1.5 - $4 \mathrm{~kg}$ per day in the study area [13]. 


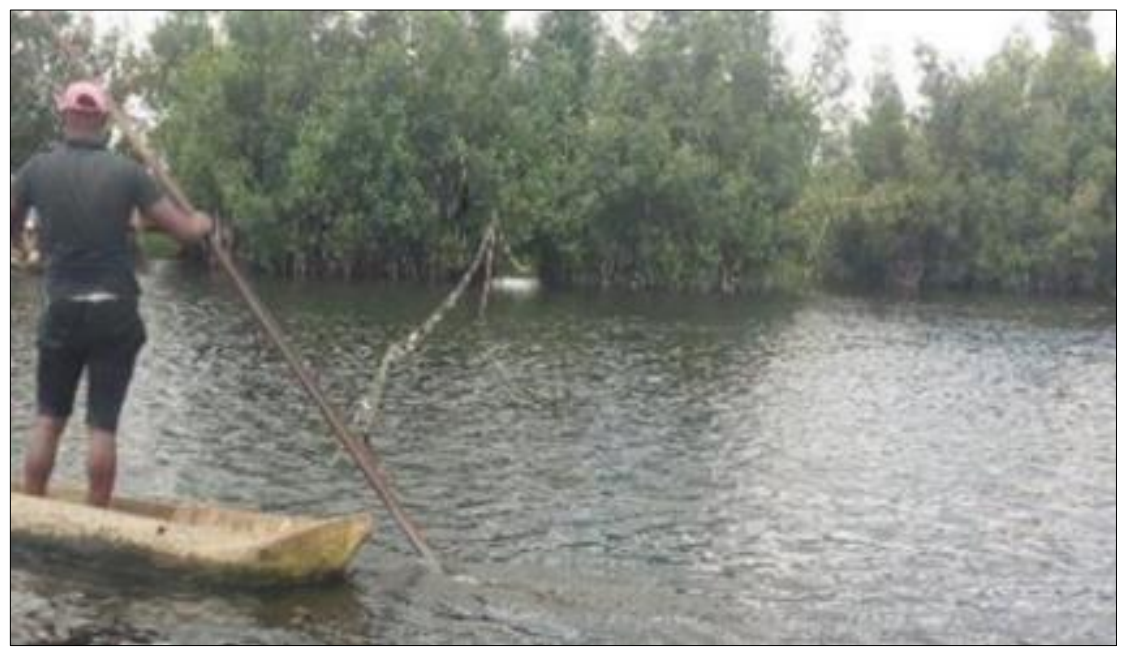

Figure 10 Fisherman placing a baited hook long line in the "Ahô channel"

\subsubsection{Unbaited hook long line "Djohoun"}

This gear differs from the previous one by the presence, the absence of baits and the very small distance between the hooks. Indeed, the distance between two hooks varies from 1.5 to $2 \mathrm{~cm}$. With these hooks, the fish are unintentionally captured by any part of their body. When setting, the fisherman, equipped with a canoe, starts from a stake to extend the hook line. Given the length of the line, a marker is placed every $50 \mathrm{~m}$ to ensure proper operation of the machine. An $18.50 \mathrm{~m}$ line has 346 hooks (fig 11). This gear does not represent a serious danger for the fauna from the point of view of the size of the species fished. But nevertheless presents a danger to other fishermen. We also note that the frequency of use of other gear decreases as this gear expands in the lake. Its use is widespread in Lake Ahémé, channel Ahô and in the lagoon of Grand-popo. The average yield of a $100 \mathrm{~m}$ line of unbaited hook long line is 2.5 - $6 \mathrm{~kg}$ per day in the study area [13].

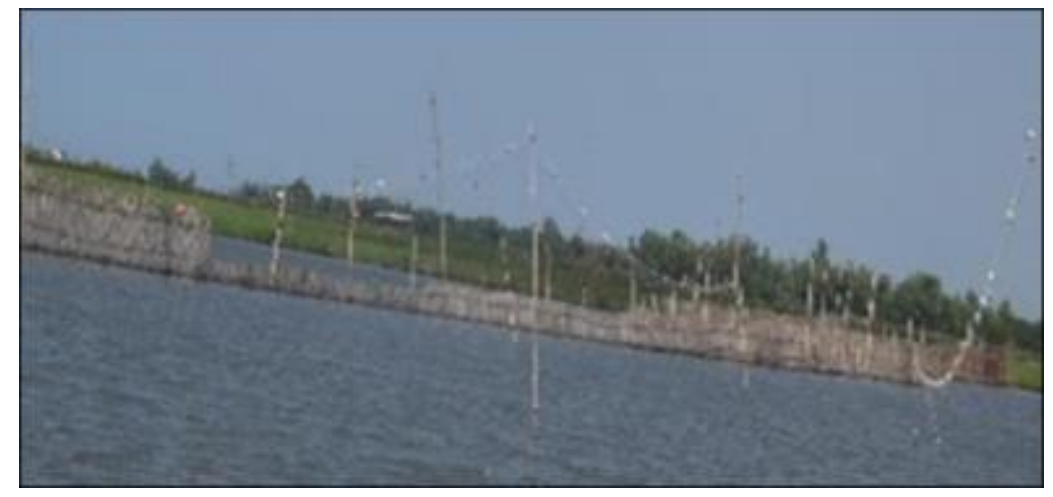

Figure 11 Unbaited hook long line set in the "Ahô channel"

\subsubsection{Bamboo "Bougué" fish traps}

It is a technique formerly practiced in Lake Ahémé, which has remained little described in the literature. Bamboo traps or "Gbodoègo" in the Minangbé language are the main method of capturing Gobiids. The contraption is made from the trunks of the plant called Bamboo (Bambousa Spp). The trunk of the plant is cylindrical in shape, with a hollow node and a solid node. Cut so as to always have two openings with a central node, they are laid longitudinally in the bottom of the lake. The fisherman takes care to remove the mud from both ends in order to facilitate the passage of the fish. The fish in the presence of this device, imagine themselves in the presence of a refuge where it is safe from predators. He enters and finds himself trapped. The bamboo traps are thus set by hundreds one after the other along a straight line always marked by a stake embedded in the water. To raise the gear, the fisherman who owns the gear called "Gbodoègonon" immerses himself in the water, plugs one end with his game bag called "Ogbin" and the other with the palm of one of his hands then raises vertically all out of the water with his second hand. The fish thus trapped on one side of the knot are overturned in the game bag and those contained in the other part are captured by analogy. Gobiidae 
fishing is quite tough. It requires breath and a great capacity of the fisherman to stay submerged in the water and / or to swim (fig 12). This is why the Gobiids are called "Gbodoè" to refer to the "ogbo" breath allusion. The average yield of 100 Bougué traps is $0.5-6 \mathrm{~kg}$ per day in the study area [13].

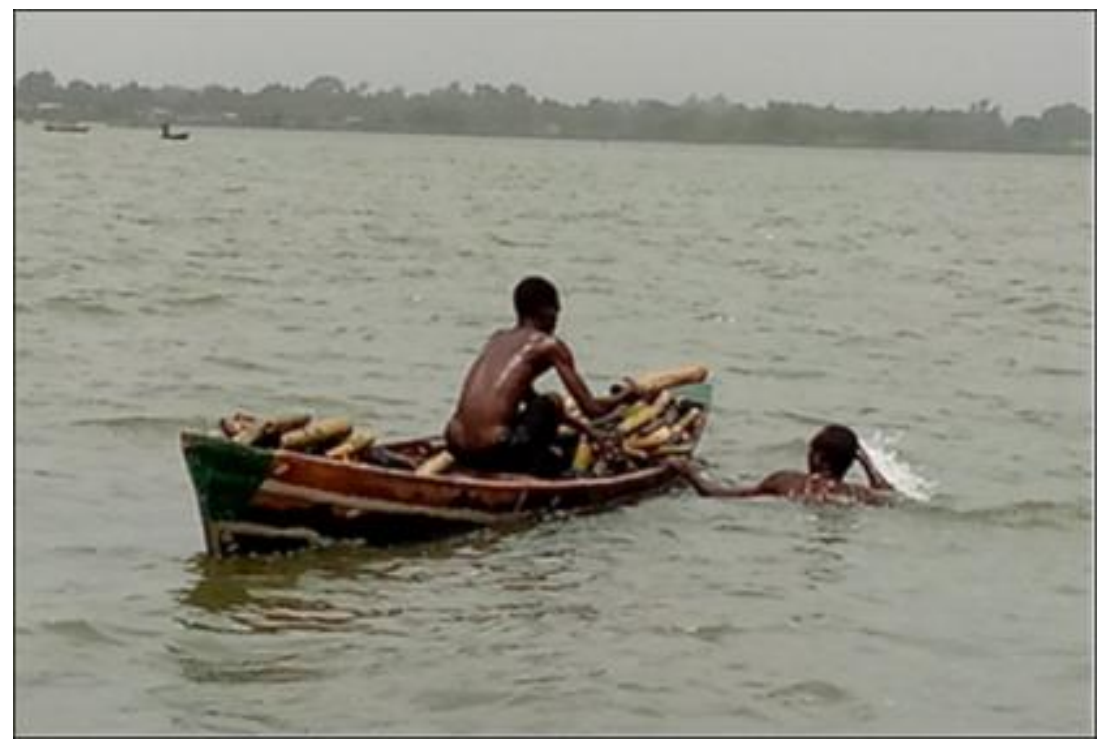

Figure 12 Fishermen putting bamboo trees in Lake Ahémé

\subsubsection{Branches Park (Acadja)}

Acadja is a Beninese appellation attributed to a traditional collective fishery practiced intensively in Lake Nokoué (Benin). It is a sort of vast artificial reef, formed of clusters of branches implanted in a lagoon in shallow areas. This facility promotes the concentration and multiplication of fish in the Acadja. The attractive effect is explained, on the one hand, by the development of microfauna and periphyton on the reefs, a substantial food source for fish, and on the other hand, by the role of refuge and shelter for I 'Acadja. The Acadja creates a favorable biotope for the biology and ethology of a colonizing species: Saroterodon melanotheron. Observations by studies by [20] have shown the high production capacity of this fishery system. Productions varying from 4 to 20 tons ha /year have been reported. Saroterodon melanotheron represents at each harvest more than $75 \%$ of the harvested biomass. However, this rewarding fishery does not only have advantages. The excessive exploitation of lagoon areas by the Acadja has resulted in harmful effects on the environment (forest clearing, bank erosion, organic pollution of the lagoon). The anarchic development of the acadjas has also created a duality with other types of exploitation such as navigation or individual fishing. This social conflict led to the ban of this practice in 1981 in the Lac Ahémé region by the local authorities of Benin [23].

The term Acadja designates branch parks and signifies any installation of fish pens made up either of branches stuck in the bottom (lagoon Acadjas) or of floating vegetation [24].

It is a sedentary fishing technique, which consists of installing branch parks in the body of water, in order to constitute a spawning area where the fish come to feed, reproduce and grow (fig 13a and 13b). 3 to 6 months after setting up the park, the fisherman surrounds it with very fine mesh nets (fig 14), to catch all the fish that are in the woodland park. This is a technique that is practiced on muddy bottoms, in all bodies of water in the study area.

Technically, the practice of Acadja is not indicated for Lake Ahémé and its channels because not only of the very narrow configuration of these bodies of water, but above all of the following problems:

- $\quad$ the impossibility for open water fishermen, for example with hawk nets and gillnets, to fish without being suspected of raiding fishermen from Acadja whose owners are a permanent threat. As fishing is the main source of income for the people living along Lake Ahémé and its channels, it is easy to understand the unfortunate consequences that such a situation engenders;

- the impossibility of traveling by canoe in certain areas of the lake because of the anarchic arrangement and the density of Acadja;

- the fragmentation of the body of water and its appropriation by the owners of Acadja, thus depriving other fishermen of their rights to practice open water fishing; 
- the role of the Acadja in the deforestation of watersheds and the cutting of mangroves which cause unbridled erosion of the soil, with the consequence of the filling of the lake mentioned by the populations and especially the practitioners of Xha.

- The filling of water bodies.

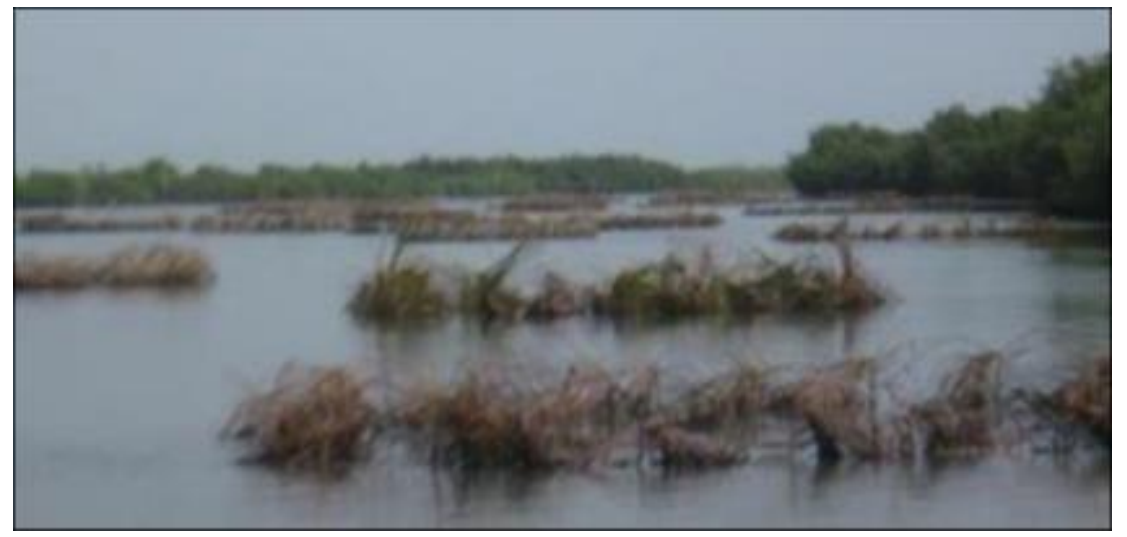

Figure 13a Acadjas parks still called Amédjrotin installed in the Ahô channel

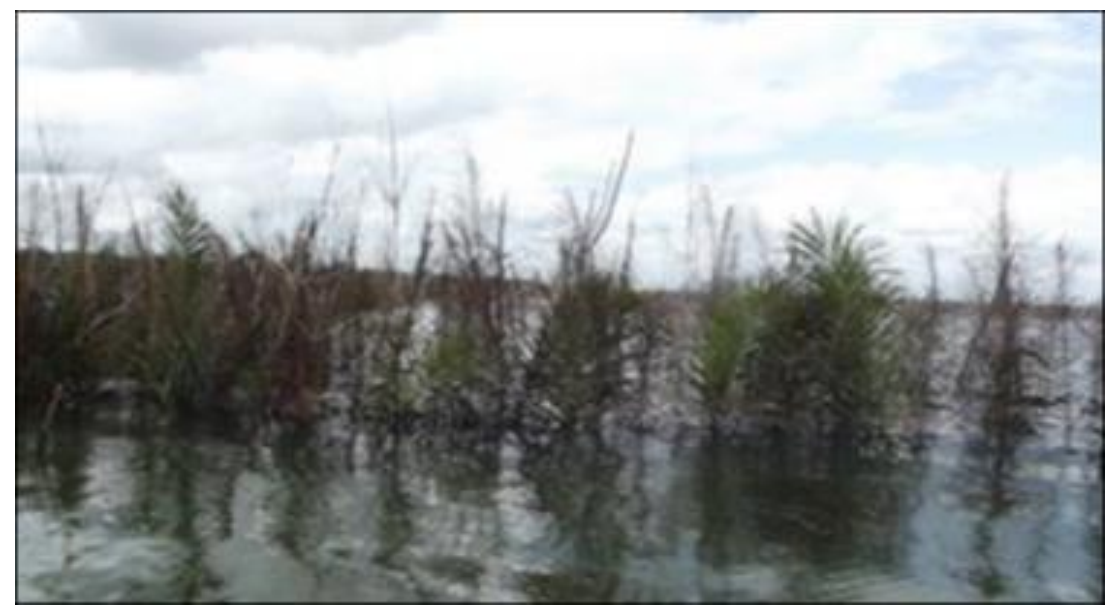

Figure 13b Acadja parks installed in Lake Ahémé

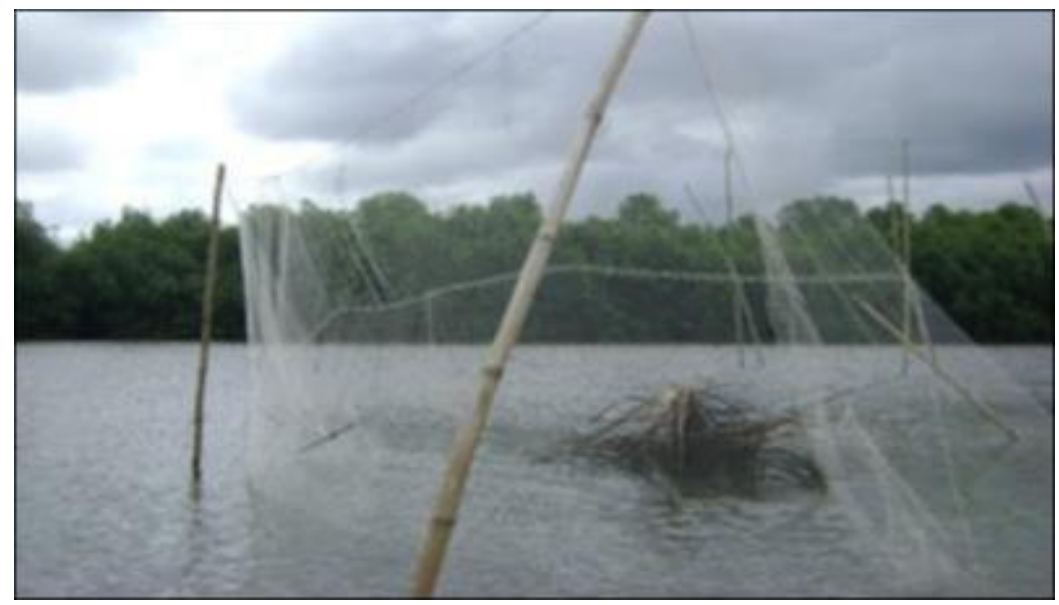

Figure 14 Acadja park in operation in the Ahô channel 


\subsubsection{Trap dam (Xha)}

These are elongated, cylindrical or conical cages surrounded by nets or raffia (fig 15). They are made from slats of $<<$ raphia >> rachis, twigs of oil palm leaves, and 3 to 5 circles of soft wooden stems. Traps are often placed in dams. They are made of openwork in slats of rachis of palm trees "raffia" or palm oil very dense braided at the lower part and armed with stakes. Sometimes 200 to $300 \mathrm{~m}$ long, these dams go from one bank to the other and constitute a real obstacle to the normal flow of water and the migration of fish. They also constitute real sediment traps and therefore contribute to the filling of water bodies. They are sometimes posed in zigzag forming a broken line with open angles in funnel each provided with a trap at their exit to catch the fish or the shrimps which engulf there. Trap dams are always installed over the entire width of the channels. They form palisades that leave a small passage near the surface of the water for canoes, the entire submerged part being blocked off. The traps capture fish and shrimp. The trap dams observed in the field have the spacing between the slats less than $3 \mathrm{~mm}$. Besides Ahémé Lake, they are installed in all other bodies of water.

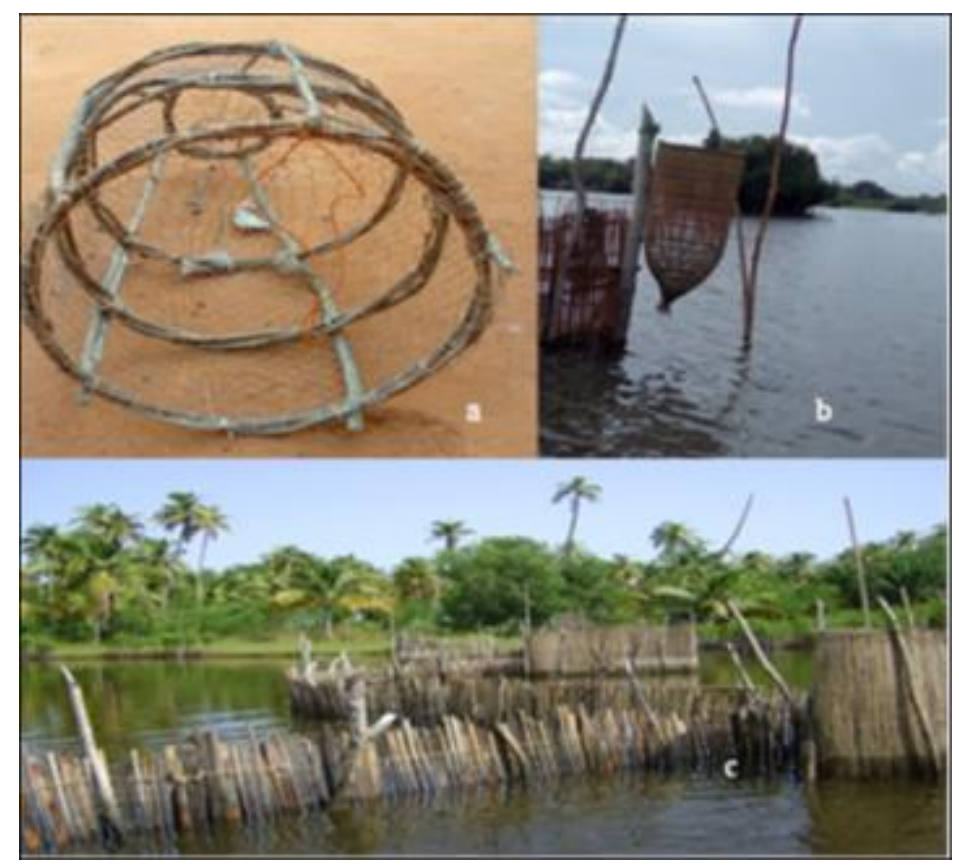

Figure 15 a) Trap surrounded by a net placed on the ground used in Ahémé Lake; b) Trap surrounded by oil bearing raffia suspended from stakes used in channel dams; c) Xha trap dam erected in the coastal lagoon of Ouidah

\subsection{Frequency of fishing gear and techniques in the Ahémé Lake area and its channels}

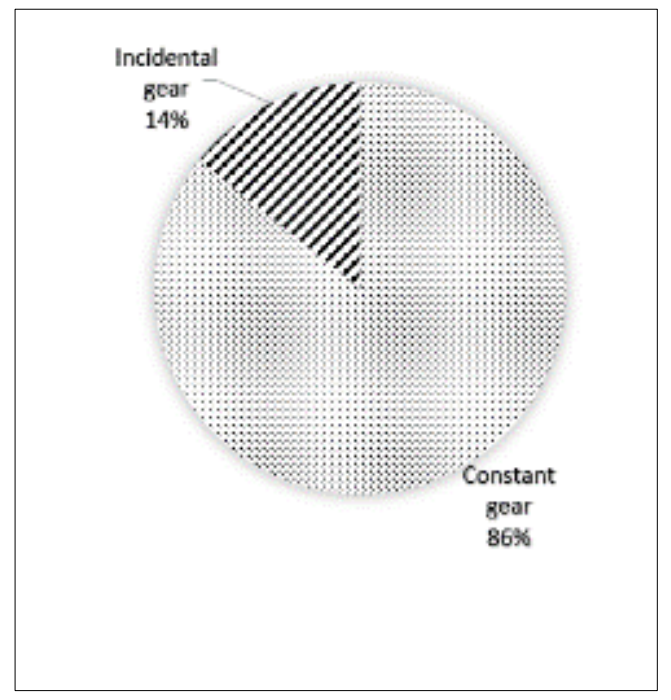

Figure 16 Occurrence of fishing gear and techniques in the Lake Ahémé area and its channels 
The percentage of occurrence calculated from the presence-absence matrix was used to determine the frequency of fishing gear during the study period. Thus, $86 \%(n=12)$ of the gears are constant. None of the gear and techniques are accidental or rare and $14 \%(n=2)$ of the gear are incidental (fig 16) during the study period.

\subsection{Variation of fishing gear and techniques by water body}

The inventory of fishing gear and techniques used in Lake Ahémé and its Channels identified a total of 14 fishing means (Table 3). Their number has varied depending on the body of water. Overall, $93 \%(n=13)$ of fishing gear and techniques were recorded in Lake Ahémé and 57\% $(n=8)$ in the Grand-Popo lagoon. The Ouidah lagoon and the Ahô channel record an equal percentage of $86 \%(n=12)$. As for the Tihimey canal, $79 \%(n=11)$ of the total number of fishing gear and techniques in the area were recorded during the study period. (fig 17).

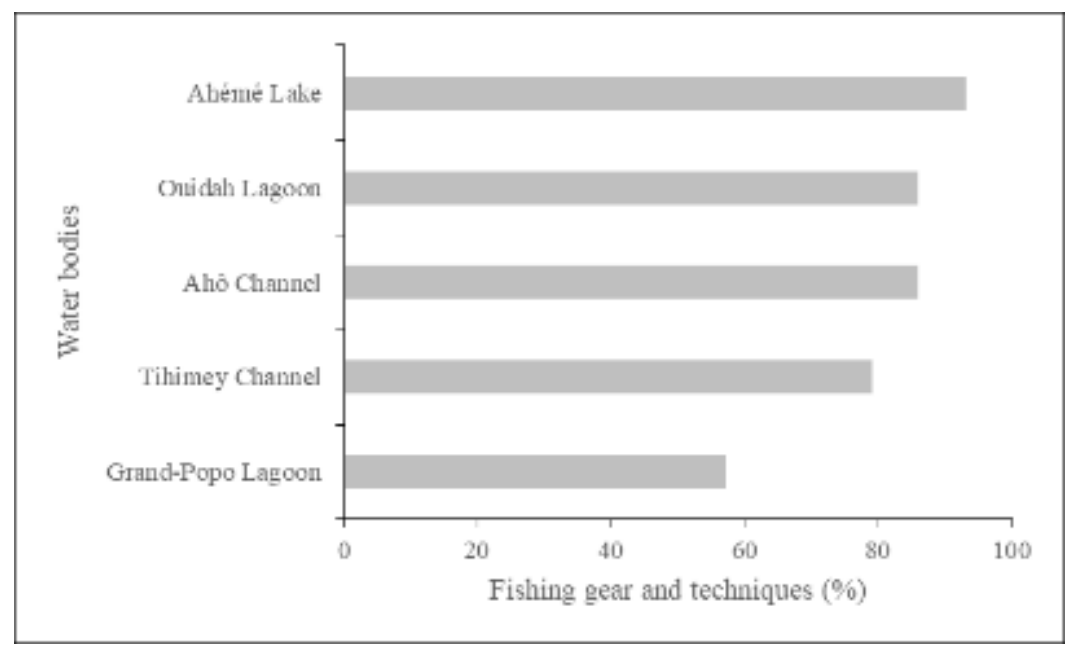

Figure 17 Variation of fishing gear and techniques by body of water

\subsection{Variation of fishing gear and techniques by station}

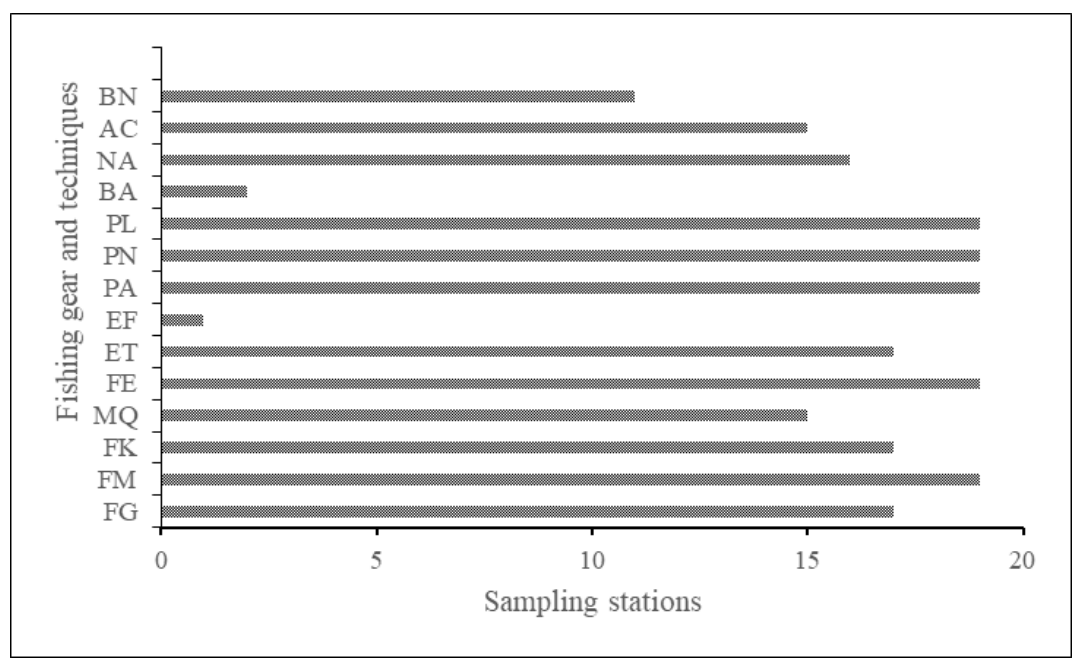

Figure 18 Variation of fishing gear and techniques by sampling station

Within the water bodies of, the fishing gear and technique varied from station to station. Thus, certain gears and techniques are found at all stations. These are gillnets (FM), cast nets (FE), angling (PL), unbaited hook longlines (PN) and baited hook longlines (PA). On the other hand, the net landing net (EF) is only found at station LA1 (Agonsa) in "Ahémé" Lake. Similarly, fishing using bamboo (BA) was observed only in stations LA4 and LA5 of Lake Ahémé On the other hand, the nets Gbagbaloulou (FG), MindokpoKonou (MK), mosquito net (MQ), Acadja (AC) and Dams at Nasses (BN) were not recorded in the LG3 and LG4 stations in the Grand-Popo lagoon. The technique of fishing using acadja is practiced in all the stations of Ouidah lagoon, Ahô channel, Ahémé Lake and Tihimey channel, ie 15 stations. Likewise, trap dams are used as fishing techniques in stations LA5, LA6, CT1, CT2, CA1, CA2, CA3, L01, LO2, LO3 and L04 (fig 18). 


\subsection{Numerical abundance and spatial occupation of fishing gear and techniques}

\subsubsection{Numerical abundance of fishing gear}

A total of 31,751 fishing gears were recorded in the area during the survey of fishermen during the study period. The abundance of devices varied numerically from device to device. Thus, the Gbagbaloulou nets represent $16.48 \%(\mathrm{n}=$ 5234) (figure 5); the gill net, Mindokpokonou net and Ethion nets represent respectively 9.73\%, 6.79\% and 8.82\% of the total number of identified gears. The Traps and "Bamboo" represent $11.26 \%$ and $8.05 \%$ of the identified gear. Baited hook longlines, hawk nets and mosquito nets occupy the respective percentages of 3.89; 12.74 and 9.73. Rod and landing net fishing lines close the list with $2.30 \%$ and $0.16 \%$ respectively (fig 19).

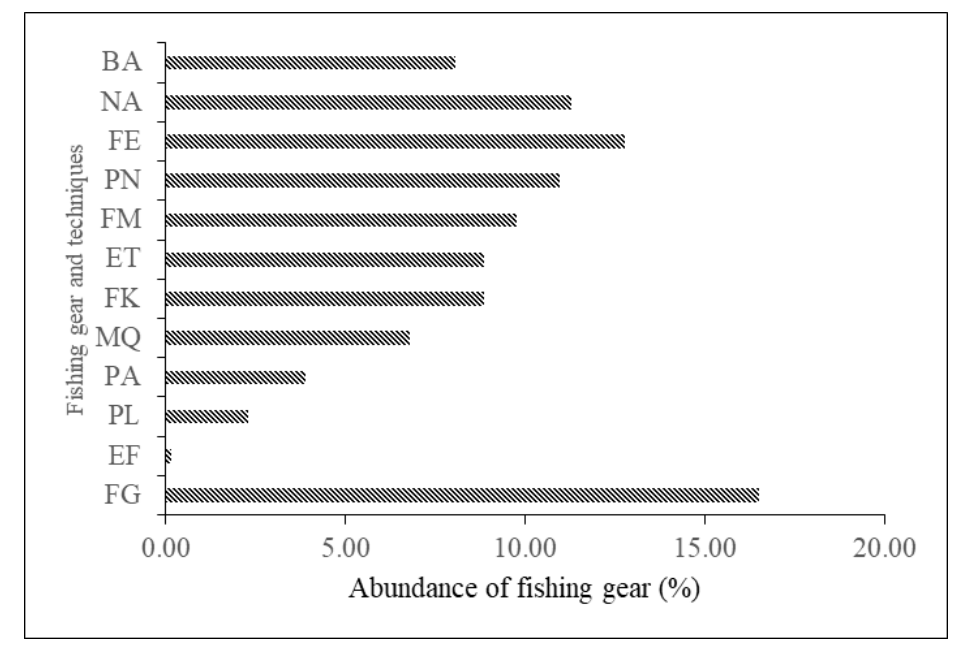

Figure 19 Numerical abundance of fishing gear

\subsubsection{Spatial occupation of fishing techniques}

The fishing techniques listed are acadja (AC) and trap dams "xhas" (BN). Fig 20 and 21 show the occupation of acadjas in "Ahémé" Lake and the channels. They show that 75\% of the surface area of "Ahémé "Lake is occupied by the Acadja, $65 \%$ in the "Ahô" channel and 35\% in the "coastal" lagoons.

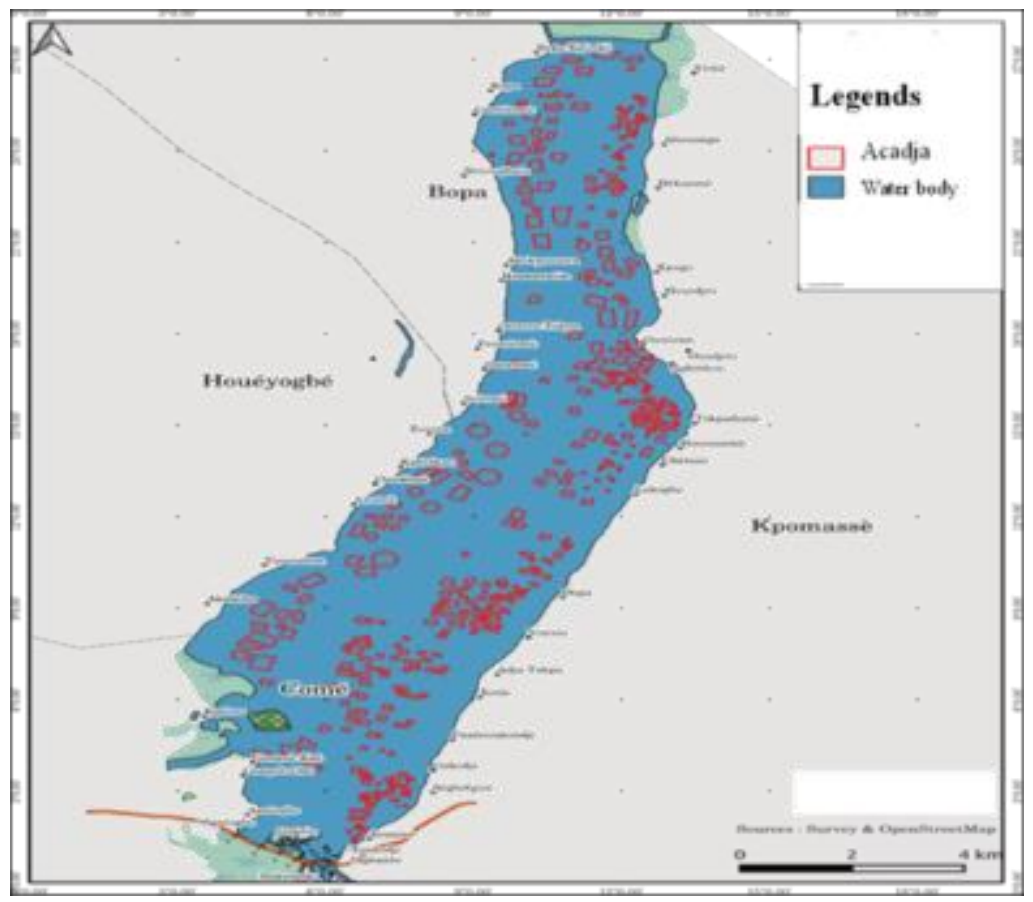

Figure 20 Spatial occupation of the Acadja in the Ahémé Lake 


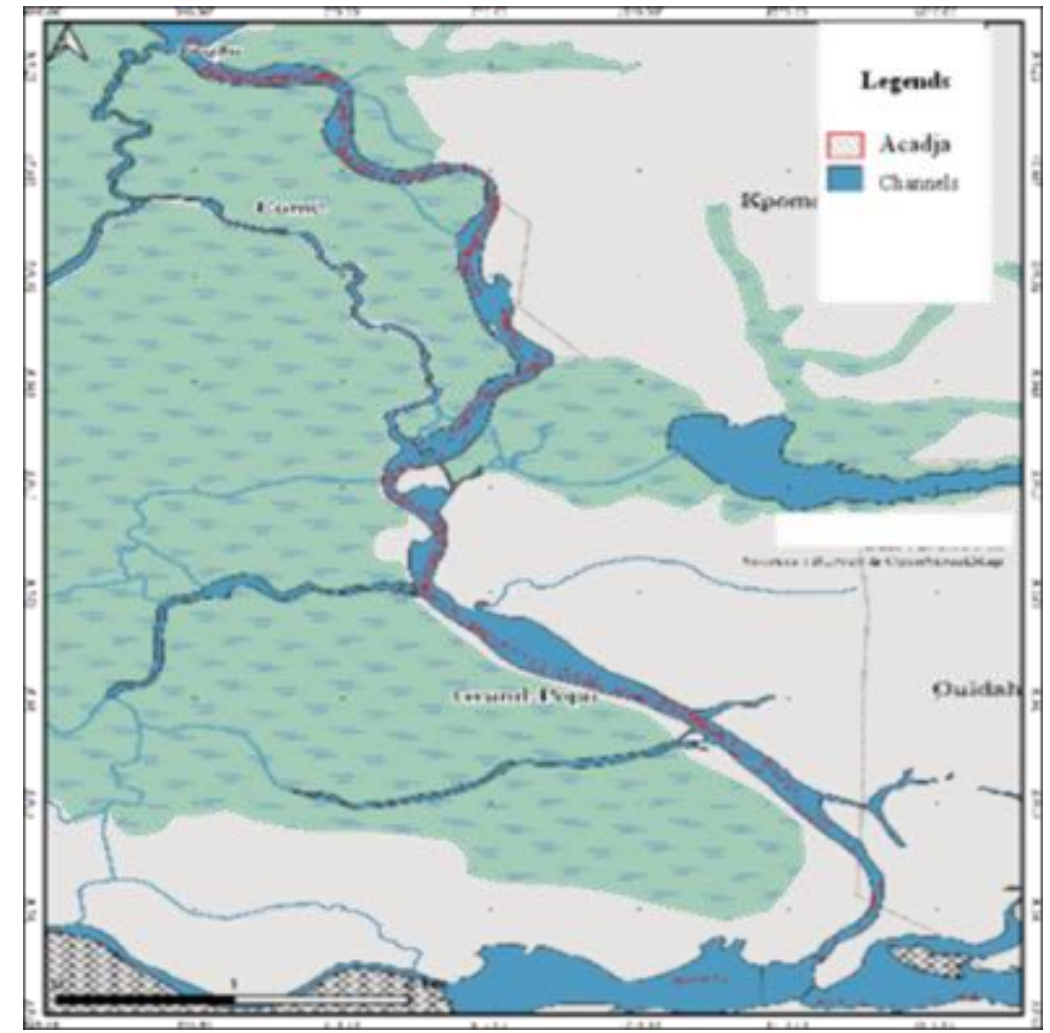

Figure 21 Spatial occupation of Acadja in the channels

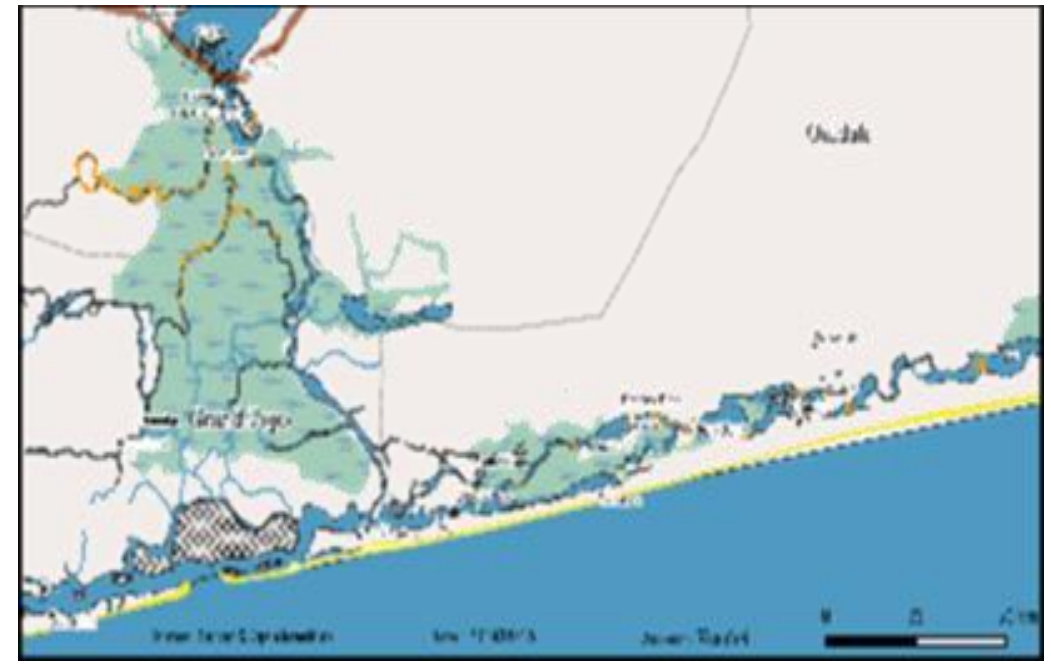

Figure 22 Spatial occupation of trap dams in the channels

\subsection{Meshes of the nets in the area of "Ahémé" Lake and its channels}

Maximum, minimum and average sizes of the drawn meshes of the nets used by fishermen in "Ahémé" Lake and its channels shown in table 3.

\subsection{Variations in the ichthyofauna caught by the fishing gear and techniques used in the Lake Ahémé area and its channels}

Fig 23 shows the variation in fish species caught by the fishing gear and techniques used in the study area. Of the 76 recorded species, the trap dams (BN), "Acadja "(AC), hawk nets (FE) and "Gbagbaloulou" nets (FG), capture 100\% of the species (tables $4 a, 4 b$, and 4c) below. In addition, gillnets (FM) and baited hook longline (PA) lines capture $97.37 \%$ and $82.89 \%$, respectively. Similarly, fishing using traps (NA) and mosquito nets (MQ) allow fishermen to catch a total of $60.53 \%$ and $57.89 \%$ of the species, respectively, while unbaited hook longline lines (PN) and rod lines capture $76.32 \%$ 
each. As for the "Ethion", (FE), dip net (EF) and Mindokpokonou (FK) nets, they respectively capture 26.32\%, 22.37\% and $39.47 \%$ of the ichthyofauna in the study area. Finally, fishing with bamboo can catch $6.58 \%$ of fish species.

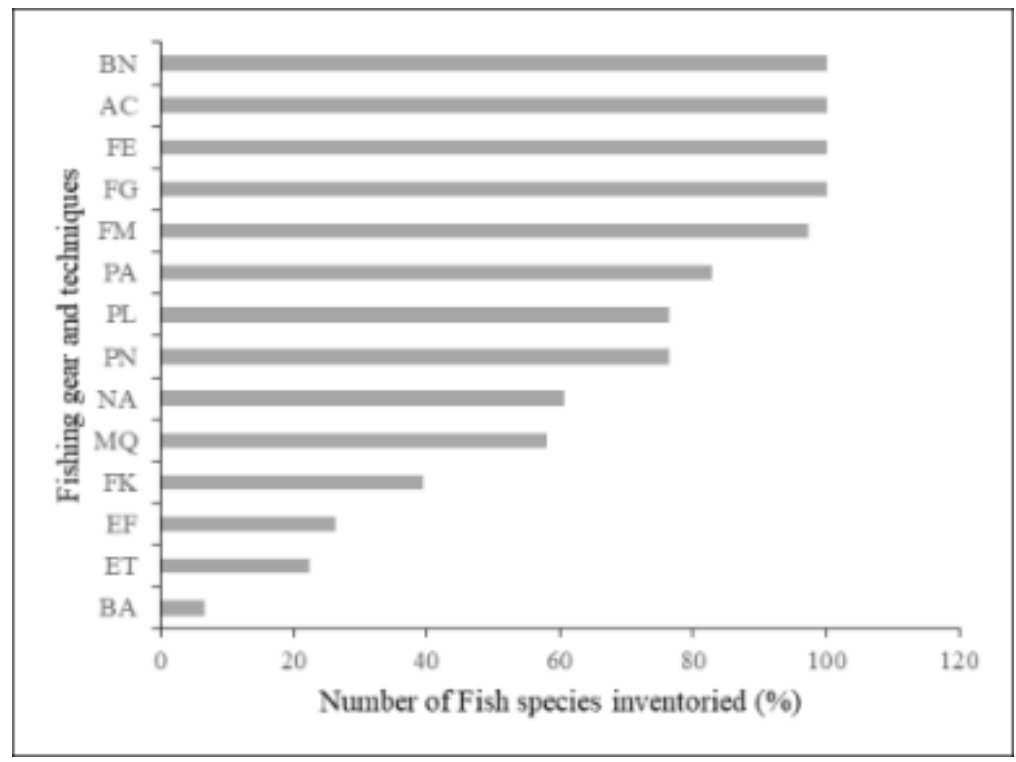

Figure 23 Variation in the number of species caught by inventoried gear and techniques

Table 3 above shows the maximum, minimum and average sizes of the drawn meshes of the nets used by fishermen in the study area. Thus, the average mesh varies from $6.5 \mathrm{~mm}$ at station LA4 in "Ahémé" Lake, to $22.5 \mathrm{~mm}$ at station LG1 in the Grand-Popo lagoon. The minimum sizes varied from $5 \mathrm{~mm}$ (LA4) to 8mm (CA1 and CA2) to 8mm; while the maximum size observed varied from $8 \mathrm{~mm}$ (LA4) to $25 \mathrm{~mm}$ (LG1). Furthermore, the average gillnet mesh observed in the area during the study period ranged from $7.5 \mathrm{~mm}$ (LA4) to $22.5 \mathrm{~mm}$ (LG2 and LG4); the minima recorded are $5 \mathrm{~mm}$ (LA4) and $20 \mathrm{~mm}$ (LG2); the maximum mesh values of this gear varied from $10 \mathrm{~mm}$ (LA1, LA4 and LO2) to $25 \mathrm{~mm}$ (LG2 and LG4). Concerning the hawk net, the minimum recorded size varied from $5 \mathrm{~mm}$ (LA4) to $20 \mathrm{~mm}$ (LG2 and LG4), while the maximum size varied from $12 \mathrm{~mm}$ (LO1 and L03) to $25 \mathrm{~mm}$ (LG2 and LG4). The "Ethion" net used in the area during the study period has a minimum mesh size varying from $2 \mathrm{~mm}$ (LA4 and LO2) to $10 \mathrm{~mm}$ (LO4, LG1, LG3 and LG4); the maximum size being $5 \mathrm{~mm}$ (LA4) to $20 \mathrm{~mm}$ (LG2). 
Table 3 Maximum, minimum and average sizes of the drawn meshes of the nets used by fishermen in "Ahémé" Lake and its channels

\begin{tabular}{|c|c|c|c|c|c|c|c|c|c|c|c|c|c|c|c|c|c|c|c|c|}
\hline \multirow[t]{2}{*}{ Fishing Net } & & \multicolumn{6}{|c|}{$\begin{array}{l}\text { "Ahémé" Lake/ } \\
\text { Code Stations }\end{array}$} & \multicolumn{2}{|c|}{$\begin{array}{l}\text { "Tihimey" } \\
\text { Channel }\end{array}$} & \multicolumn{3}{|c|}{$\begin{array}{c}\text { "Ahô" } \\
\text { Channel }\end{array}$} & \multicolumn{4}{|c|}{ Lagoon of Ouidah } & \multicolumn{4}{|c|}{ Lagoon of Grand-Popo } \\
\hline & & LA1 & LA2 & LA3 & LA4 & LA5 & LA6 & CT1 & CT2 & CA1 & CA2 & CA3 & L01 & LO2 & L03 & LO4 & LG1 & LG2 & LG3 & LG4 \\
\hline \multirow{3}{*}{$\begin{array}{l}\text { "Gbagbaloulou" } \\
\text { net }\end{array}$} & MAX & 15 & 17 & 15 & 8 & 12 & 15 & 12 & 15 & 10 & 10 & 15 & 20 & 15 & 12 & 15 & 25 & 15 & - & - \\
\hline & MIN & 7 & 9 & 7 & 5 & 10 & 10 & 10 & 10 & 8 & 8 & 10 & 15 & 12 & 10 & 10 & 20 & 10 & - & - \\
\hline & MOY & 11 & 13 & 11 & 6,5 & 11 & 12,5 & 11 & 12,5 & 9 & 9 & 12,5 & 17,5 & 13,5 & 11 & 12,5 & 22,5 & 12,5 & - & - \\
\hline \multirow{3}{*}{$\begin{array}{l}\text { "Mesh net" } \\
\text { (Tohounga) }\end{array}$} & MAX & 10 & 15 & 15 & 10 & 15 & 15 & 12 & 15 & 15 & 15 & 15 & 12 & 10 & 15 & 17 & 20 & 25 & 20 & 25 \\
\hline & MIN & 8 & 10 & 10 & 5 & 10 & 10 & 8 & 10 & 10 & 10 & 10 & 10 & 5 & 10 & 15 & 15 & 20 & 15 & 20 \\
\hline & MOY & 9 & 12,5 & 12,5 & 7,5 & 12,5 & 12,5 & 10 & 12,5 & 12,5 & 12,5 & 12,5 & 11 & 7,5 & 12,5 & 16 & 17,5 & 22,5 & 17,5 & 22,5 \\
\hline \multirow{3}{*}{ "Hawk" net } & MAX & 15 & 15 & 15 & 15 & 15 & 15 & 15 & 15 & 15 & 15 & 15 & 12 & 15 & 12 & 15 & 20 & 25 & 20 & 25 \\
\hline & MIN & 8 & 10 & 10 & 5 & 10 & 10 & 8 & 10 & 10 & 10 & 10 & 10 & 10 & 8 & 10 & 15 & 20 & 15 & 20 \\
\hline & MOY & 11,5 & 12,5 & 12,5 & 10 & 12,5 & 12,5 & 11,5 & 12,5 & 12,5 & 12,5 & 12,5 & 11 & 12,5 & 10 & 12,5 & 17,5 & 22,5 & 17,5 & 22,5 \\
\hline \multirow{3}{*}{ "Ethion" net } & MAX & 8 & 10 & 10 & 5 & 10 & 10 & 8 & 10 & 10 & 10 & 10 & 10 & 5 & 10 & 15 & 15 & 20 & 15 & 15 \\
\hline & MIN & 5 & 5 & 8 & 2 & 5 & 5 & 5 & 5 & 5 & 5 & 5 & 5 & 2 & 5 & 10 & 10 & 15 & 10 & 10 \\
\hline & MOY & 6,5 & 7,5 & 9 & 3,5 & 7,5 & 7,5 & 6,5 & 7,5 & 7,5 & 7,5 & 7,5 & 7,5 & 3,5 & 7,5 & 12,5 & 12,5 & 17,5 & 12,5 & 12,5 \\
\hline \multirow{3}{*}{ Net landing } & MAX & 15 & 0 & 0 & 0 & 0 & 0 & 0 & 0 & 0 & 0 & 0 & 0 & 0 & 0 & 0 & 0 & 0 & 0 & 0 \\
\hline & MIN & 8 & 0 & 0 & 0 & 0 & 0 & 0 & 0 & 0 & 0 & 0 & 0 & 0 & 0 & 0 & 0 & 0 & 0 & 0 \\
\hline & MOY & 11,5 & 0 & 0 & 0 & 0 & 0 & 0 & 0 & 0 & 0 & 0 & 0 & 0 & 0 & 0 & 0 & 0 & 0 & 0 \\
\hline
\end{tabular}


Table 4a Species caught by the gear and techniques used in "Ahémé" Lake and its channels

\begin{tabular}{|c|c|c|c|c|c|c|c|c|c|c|c|c|c|c|}
\hline Gender/Species & FG & FM & FK & MQ & FE & ET & $\mathbf{E F}$ & PA & PN & PL & BA & NA & AC & BN \\
\hline Acanthurus monroviae & 1 & 1 & 0 & 0 & 1 & 0 & 0 & 0 & 0 & 1 & 0 & 0 & 1 & 1 \\
\hline Ctenopoma petherici & 1 & 1 & 1 & 1 & 1 & 0 & 0 & 0 & 0 & 1 & 0 & 0 & 1 & 1 \\
\hline Strongylura senegalensis & 1 & 1 & 0 & 0 & 1 & 0 & 0 & 0 & 0 & 0 & 0 & 0 & 1 & 1 \\
\hline Caranx hippos & 1 & 1 & 0 & 0 & 1 & 0 & 0 & 1 & 1 & 1 & 0 & 0 & 1 & 1 \\
\hline Chloroscombrus chrysurus & 1 & 1 & 0 & 0 & 1 & 0 & 0 & 1 & 1 & 1 & 0 & 0 & 1 & 1 \\
\hline Selene dorsalis & 1 & 1 & 0 & 0 & 1 & 0 & 0 & 1 & 1 & 0 & 0 & 0 & 1 & 1 \\
\hline Trachinotus goreensis & 1 & 1 & 0 & 0 & 1 & 0 & 0 & 1 & 1 & 0 & 0 & 0 & 1 & 1 \\
\hline Trachinotus teraia & 1 & 1 & 0 & 0 & 1 & 0 & 0 & 1 & 1 & 1 & 0 & 0 & 1 & 1 \\
\hline Lates niloticus & 1 & 1 & 1 & 1 & 1 & 0 & 1 & 1 & 1 & 1 & 0 & 0 & 1 & 1 \\
\hline Parachanna obscura & 1 & 0 & 0 & 1 & 1 & 0 & 0 & 1 & 1 & 1 & 0 & 1 & 1 & 1 \\
\hline Hemichromis bimaculatus & 1 & 1 & 1 & 1 & 1 & 1 & 1 & 1 & 1 & 1 & 0 & 1 & 1 & 1 \\
\hline Hemichromis elongatus & 1 & 1 & 1 & 1 & 1 & 1 & 1 & 1 & 1 & 1 & 0 & 1 & 1 & 1 \\
\hline Hemichromis fasciatus & 1 & 1 & 1 & 1 & 1 & 1 & 1 & 1 & 1 & 1 & 0 & 1 & 1 & 1 \\
\hline Oreochromis niloticus & 1 & 1 & 1 & 1 & 1 & 1 & 1 & 1 & 1 & 1 & 0 & 1 & 1 & 1 \\
\hline Sarotherodon melanotheron & 1 & 1 & 1 & 1 & 1 & 1 & 1 & 1 & 1 & 1 & 0 & 1 & 1 & 1 \\
\hline Coptodon guineensis & 1 & 1 & 1 & 1 & 1 & 1 & 1 & 1 & 1 & 1 & 0 & 1 & 1 & 1 \\
\hline Clarias ebriensis & 1 & 1 & 1 & 1 & 1 & 0 & 0 & 1 & 1 & 1 & 0 & 1 & 1 & 1 \\
\hline Clarias agboyiensis & 1 & 1 & 1 & 1 & 1 & 0 & 0 & 1 & 1 & 1 & 0 & 1 & 1 & 1 \\
\hline Clarias gariepinus & 1 & 1 & 1 & 1 & 1 & 0 & 0 & 1 & 1 & 1 & 0 & 1 & 1 & 1 \\
\hline Chrysichthys nigrodigitatus & 1 & 1 & 1 & 1 & 1 & 0 & 1 & 1 & 1 & 1 & 0 & 1 & 1 & 1 \\
\hline Chrysichthys auratus & 1 & 1 & 1 & 1 & 1 & 0 & 1 & 1 & 1 & 1 & 0 & 1 & 1 & 1 \\
\hline Laeviscutella dekimpei & 1 & 1 & 1 & 1 & 1 & 0 & 0 & 1 & 1 & 1 & 0 & 1 & 1 & 1 \\
\hline Ethmalosa fimbriata & 1 & 1 & 1 & 1 & 1 & 0 & 0 & 1 & 1 & 1 & 0 & 1 & 1 & 1 \\
\hline Sardinella maderensis & 1 & 1 & 1 & 1 & 1 & 0 & 0 & 1 & 1 & 1 & 0 & 1 & 1 & 1 \\
\hline Pellonula leonensis & 1 & 1 & 1 & 1 & 1 & 0 & 0 & 1 & 1 & 1 & 0 & 1 & 1 & 1 \\
\hline Sierrathrissa leonensis & 1 & 1 & 0 & 0 & 1 & 0 & 0 & 1 & 1 & 1 & 0 & 0 & 1 & 1 \\
\hline Cynoglossus senegalensis & 1 & 1 & 0 & 0 & 1 & 0 & 0 & 1 & 0 & 0 & 0 & 0 & 1 & 1 \\
\hline Raiamas senegalensis & 1 & 1 & 0 & 0 & 1 & 0 & 0 & 1 & 0 & 0 & 0 & 0 & 1 & 1 \\
\hline Labeo senegalensis & 1 & 1 & 0 & 0 & 1 & 0 & 0 & 1 & 0 & 0 & 0 & 0 & 1 & 1 \\
\hline Dasyatis margarita & 1 & 1 & 0 & 0 & 1 & 0 & 0 & 1 & 0 & 0 & 0 & 0 & 1 & 1 \\
\hline Dormitator lebretonis & 1 & 1 & 0 & 0 & 1 & 0 & 0 & 1 & 0 & 0 & 0 & 0 & 1 & 1 \\
\hline Kribia kribensis & 1 & 0 & 1 & 1 & 1 & 1 & 0 & 0 & 0 & 0 & 0 & 0 & 1 & 1 \\
\hline Eleotris senegalensis & 1 & 1 & 1 & 1 & 1 & 0 & 1 & 1 & 1 & 1 & 0 & 1 & 1 & 1 \\
\hline Eleotris vittata & 1 & 1 & 1 & 1 & 1 & 0 & 1 & 1 & 1 & 1 & 0 & 1 & 1 & 1 \\
\hline Elops senegalensis & 1 & 1 & 1 & 1 & 1 & 0 & 1 & 1 & 1 & 1 & 0 & 1 & 1 & 1 \\
\hline
\end{tabular}


Table 4b Species caught by the gear and techniques used in "Ahémé"3 Lake and its channels (continued)

\begin{tabular}{|c|c|c|c|c|c|c|c|c|c|c|c|c|c|c|}
\hline Gender/Species & FG & FM & FK & MQ & $\mathbf{F E}$ & ET & $\mathbf{E F}$ & PA & PN & PL & BA & NA & AC & BN \\
\hline Elops lacerta & 1 & 1 & 1 & 1 & 1 & 0 & 1 & 1 & 1 & 1 & 0 & 1 & 1 & 1 \\
\hline Gerres nigri & 1 & 1 & 0 & 0 & 1 & 0 & 0 & 1 & 1 & 1 & 0 & 0 & 1 & 1 \\
\hline Eucinostomus melanopterus & 1 & 1 & 0 & 0 & 1 & 0 & 0 & 1 & 1 & 1 & 0 & 0 & 1 & 1 \\
\hline Awaous lateristriga & 1 & 1 & 0 & 0 & 1 & 0 & 0 & 1 & 1 & 1 & 0 & 0 & 1 & 1 \\
\hline Bathygobius soporator & 1 & 1 & 1 & 1 & 1 & 1 & 0 & 0 & 0 & 0 & 1 & 1 & 1 & 1 \\
\hline Gobioides sagitta & 1 & 1 & 1 & 1 & 1 & 1 & 0 & 0 & 0 & 0 & 1 & 1 & 1 & 1 \\
\hline Gobionellus occidentalis & 1 & 1 & 1 & 1 & 1 & 1 & 0 & 0 & 0 & 0 & 1 & 1 & 1 & 1 \\
\hline Periophthalmus barbarus & 1 & 1 & 1 & 1 & 1 & 1 & 0 & 0 & 0 & 0 & 1 & 1 & 1 & 1 \\
\hline Porogobius schlegelii & 1 & 1 & 1 & 1 & 1 & 1 & 0 & 0 & 0 & 0 & 1 & 1 & 1 & 1 \\
\hline Pomadasys jubelini & 1 & 1 & 0 & 0 & 1 & 0 & 0 & 1 & 1 & 1 & 0 & 0 & 1 & 1 \\
\hline Pomadasys peroteti & 1 & 1 & 0 & 0 & 1 & 0 & 0 & 1 & 1 & 1 & 0 & 0 & 1 & 1 \\
\hline Hyporamphus picarti & 1 & 1 & 0 & 0 & 1 & 0 & 0 & 1 & 1 & 1 & 0 & 0 & 1 & 1 \\
\hline Hepsetus odoe & 1 & 1 & 0 & 0 & 1 & 0 & 0 & 1 & 1 & 1 & 0 & 0 & 1 & 1 \\
\hline Lutjanus agennes & 1 & 1 & 0 & 0 & 1 & 0 & 0 & 1 & 1 & 1 & 0 & 0 & 1 & 1 \\
\hline Lutjanus endecacanthus & 1 & 1 & 0 & 0 & 1 & 0 & 0 & 1 & 1 & 1 & 0 & 0 & 1 & 1 \\
\hline Lutjanus goreensis & 1 & 1 & 0 & 0 & 1 & 0 & 0 & 1 & 1 & 1 & 0 & 0 & 1 & 1 \\
\hline Tarpon atlanticus & 1 & 1 & 0 & 0 & 1 & 0 & 0 & 1 & 1 & 1 & 0 & 0 & 1 & 1 \\
\hline Synodontis nigrita & 1 & 1 & 1 & 1 & 1 & 0 & 1 & 1 & 1 & 1 & 0 & 1 & 1 & 1 \\
\hline Synodontis schall & 1 & 1 & 0 & 0 & 1 & 0 & 1 & 1 & 1 & 1 & 0 & 1 & 1 & 1 \\
\hline Monodactylus sebae & 1 & 1 & 0 & 0 & 1 & 0 & 0 & 1 & 1 & 1 & 0 & 0 & 1 & 1 \\
\hline Mormyrops anguilloides & 1 & 1 & 0 & 0 & 1 & 0 & 0 & 1 & 1 & 1 & 0 & 0 & 1 & 1 \\
\hline Liza falcipinnis & 1 & 1 & 0 & 1 & 1 & 0 & 0 & 1 & 1 & 1 & 0 & 1 & 1 & 1 \\
\hline Mugil cephalus & 1 & 1 & 0 & 1 & 1 & 0 & 0 & 1 & 1 & 1 & 0 & 1 & 1 & 1 \\
\hline Dalophis boulengeri & 1 & 1 & 0 & 0 & 1 & 1 & 1 & 0 & 0 & 0 & 0 & 1 & 1 & 1 \\
\hline Dalophis cephalopeltis & 1 & 1 & 0 & 0 & 1 & 1 & 1 & 0 & 0 & 0 & 0 & 1 & 1 & 1 \\
\hline Heterotis niloticus & 1 & 1 & 0 & 0 & 1 & 1 & 1 & 0 & 0 & 0 & 0 & 1 & 1 & 1 \\
\hline Citharichthys stampflii & 1 & 1 & 0 & 0 & 1 & 0 & 0 & 0 & 0 & 0 & 0 & 1 & 1 & 1 \\
\hline Polypterus senegalus senegalus & 1 & 1 & 0 & 1 & 1 & 0 & 0 & 1 & 1 & 1 & 0 & 1 & 1 & 1 \\
\hline Polypterus endlicheri endlicheri & 1 & 1 & 0 & 1 & 1 & 0 & 0 & 1 & 1 & 1 & 0 & 1 & 1 & 1 \\
\hline Galeoides decadactylus & 1 & 1 & 0 & 1 & 1 & 0 & 0 & 1 & 1 & 1 & 0 & 1 & 1 & 1 \\
\hline Polydactylus quadrifilis & 1 & 1 & 0 & 1 & 1 & 0 & 0 & 1 & 1 & 1 & 0 & 1 & 1 & 1 \\
\hline
\end{tabular}


Table 4c Species caught by the gear and techniques used in "Ahémé" Lake and its channels (continued)

\begin{tabular}{|l|c|c|c|c|c|c|c|c|c|c|c|c|c|c|}
\hline Gender/Species & FG & FM & FK & MQ & FE & ET & EF & PA & PN & PL & BA & NA & AC & BN \\
\hline Protopterus annectens annectens & 1 & 1 & 0 & 0 & 1 & 0 & 0 & 1 & 1 & 1 & 0 & 0 & 1 & 1 \\
\hline Schilbe intermedius & 1 & 1 & 1 & 1 & 1 & 1 & 1 & 1 & 1 & 1 & 0 & 1 & 1 & 1 \\
\hline Schilbe mystus & 1 & 1 & 1 & 1 & 1 & 1 & 1 & 1 & 1 & 1 & 0 & 1 & 1 & 1 \\
\hline Pseudotolithus senegalensis & 1 & 1 & 0 & 1 & 1 & 0 & 0 & 1 & 1 & 1 & 0 & 1 & 1 & 1 \\
\hline Scomberomorus tritor & 1 & 1 & 0 & 1 & 1 & 0 & 0 & 1 & 1 & 1 & 0 & 1 & 1 & 1 \\
\hline Epinephelus marginatus & 1 & 1 & 0 & 1 & 1 & 0 & 0 & 1 & 1 & 1 & 0 & 1 & 1 & 1 \\
\hline Epinephelus aeneus & 1 & 1 & 0 & 1 & 1 & 0 & 0 & 1 & 1 & 1 & 0 & 1 & 1 & 1 \\
\hline Dagetichthys lakdoensis & 1 & 1 & 0 & 1 & 1 & 0 & 0 & 1 & 1 & 1 & 0 & 1 & 1 & 1 \\
\hline Synaptura lusitanica & 1 & 1 & 0 & 1 & 1 & 0 & 0 & 1 & 1 & 1 & 0 & 1 & 1 & 1 \\
\hline Tetraodon pustulatus & 1 & 1 & 0 & 1 & 1 & 0 & 0 & 1 & 1 & 1 & 0 & 1 & 1 & 1 \\
\hline TOTAL & $\mathbf{7 6}$ & $\mathbf{7 4}$ & $\mathbf{3 0}$ & $\mathbf{4 4}$ & $\mathbf{7 6}$ & $\mathbf{1 7}$ & $\mathbf{2 0}$ & $\mathbf{6 3}$ & $\mathbf{5 8}$ & $\mathbf{5 8}$ & $\mathbf{5}$ & $\mathbf{4 6}$ & $\mathbf{7 6}$ & $\mathbf{7 6}$ \\
\hline
\end{tabular}

\section{Discussion}

In the area of Lake Ahémé and its channels, ten gear and two fishing techniques have been inventoried and described. These results are superior to most of those obtained in other water bodies in Benin and in the African sub-region. Indeed, [25] counted 8 fishing gears and techniques in the Lower Ouémé Valley, [26] as for them, identified 7 fishing gears and techniques on the lagoon complex Lake Nokoué and Porto-Novo lagoon. In addition, [27] inventoried 6 fishing gears and techniques on the lagoons of Togo, while [28] noted the presence of 4 fishing gears in the fisheries of Boubon in Niger, [29] obtained 7 fishing gear and techniques on Lake Borkou in Tchad and [30] identified 5 fishing gear and techniques on Lake Tanganika. On the other hand, the results of the present study are much lower than those obtained by [31] in the Sine Saloum estuary in Senegal, where 25 fishing gears and techniques were inventoried. These results are justified by the size of the study area. They show that the study area is under strong fishing pressure in view of the diversity of fishing gear and techniques used; which constitutes a cause of degradation of the aquatic ecosystem [32]. The occurrence of the gears showed that $86 \%$ of the gears are constant and $14 \%$ of the gears are accessory in the study area. The Acadjas, trap dams, Mindokpokonou nets and Gbagbaloulou nets are among the constant gear. These results are similar to those obtained by [33] at Lake Nokoué and the Porto-Novo lagoon where fishing gear and techniques are dominated by these 4 techniques. The landing net introduced north of Lake Ahémé is part of the accessory fishing gear and techniques. This result is consistent with that obtained by [30] at Lake Tanganika. Fishing gear and techniques have varied according to the water bodies and the sampling stations. In fact, in addition to the richness of fish species, the configuration and depth of the water are parameters that determine the gear used [34]. The shallow depth of the water bodies in the study area favors the use of most of the fishing gear and techniques identified [35].

\subsection{Legal arsenal relating to fishing gear and techniques in Benin}

In the area of "Ahémé" Lake and its channels, ten gear and two fishing techniques have been inventoried and described. In light of the conservation measures for fishery resources and aquatic ecosystems contained in FRAMEWORK LAW N - 2014-19 OF AUGUST 07, 2014 [36] relating to fishing and aquaculture in the Republic of Benin, certain gear and techniques are prohibited. Indeed, according to the provisions of Article 73 of the said law, it is prohibited: a) to use, in the exercise of inland or sea fishing, fishing gear or methods incompatible with the sustainable management of fish stocks, especially :

- any fish park, whatever its shape or size, built using branches fixed to the bottom of rivers, lakes or lagoons, or any other place serving as refuge, reproduction and development of fish, and being able to increase the natural productivity of water bodies ("Acadja", ... etc);

- any conical-shaped fishing gear fitted with a pocket in the background, placed and wedged against the current across watercourses, and used in periods of recession to fish for fish and shellfish (" Dogbo ",... etc); 
- any fishing gear with several pockets, having a tapered shape, made from a very fine mesh net and supported by hoops, used for catching shrimps, crabs and fish fry ("Gbagbaloulou", etc.) ;

- any fishing gear made from sheets of nets with very narrow meshes and consisting of a long rectangular arm and pockets at each end in which are arranged collecting traps whose arm carries floats to the top rope and weights to the lower bolt rope and serves as a guide for fish and shellfish to one of the pocket entrances ("Mindokpokonou" or "Tokpokonou" or "Tokplékonou", etc.);

- any trap dam built using branches, wood, poles, bamboo and / or other plant materials placed through the passage of aquatic fauna, thus constituting a right trap for fish and crustaceans ("won" or "Xha" or "Adjakpa", etc).

- to place nets, dams, devices or other processes the object or effect of which is to block the course of rivers or streams or to obstruct the entrance to lagoons, estuaries or river mouths for fishing purposes;

- to use the ox trawl in industrial or artisanal maritime fishing.

With regard to the provisions of this article, the prohibited gear and techniques are set nets "Gbagbaloulou", "Mindokpokonou", "Mosquito" nets, unbaited hook longlines, "Acadja" and "Xhas". On the other hand, without authorizing them, the law remained silent on the nets of hawk, gill, landing net, ethion, rod and hook fishing and bamboo; which assumes that they can be used without breaking any regulations.

"Gbagbaloulou"," Mindokopkonou" and "Mosquito" nets are prohibited because of the damage they cause to resources. In effect, these nets capture fish at different stages of their life cycle (eggs, larvae, fry, fingerlings and fish). Likewise, their exploitation causes turbidity of the water; which causes plugging of the gills and the death of fish by asphyxiation. Regarding Acadja and Xhas, they are prohibited in view of the nuisance caused to the human environment, the aquatic ecosystem and the fishery resources. Indeed, their establishment requires tree branches. Thus, trees located in the immediate environment of these bodies of water undergo frequent cutting operations. However, these trees play the role of purification of the ambient air through the phenomenon of carbon assimilation or photosynthesis. As a result, the air breathed by the populations is polluted, precipitation is scarce; all things that contribute to climate change. These techniques are not without negative consequences for fish species and the aquatic ecosystem. In fact, when operating the "Acadjas", the nets used are not selective. Thus, all species found in "Acadja" Park are fished regardless of their size. In addition, the "Acadja" residues are left in the water and their sedimentation contributes to the filling of water bodies. As for the "Xha" trap dams, in addition to the damage caused to the environment by cutting palm trees and bamboo, they destroy the aquatic ecosystem by retaining the floating elements carried by the water current. These elements retained, sediment and also contribute to the filling of water bodies. It should also be noted that these techniques are also installed in the channels which are migration corridors for fish from the sea to the continent and vice versa. Reasons why "Acadja" and "Xha" are prohibited by law.

The law provides for penalties for infringements in articles 112 to 116 . In fact, according to the provisions of article 112: Are punished by a fine of five hundred thousand $(500,000)$ CFA francs to three millions $(3,000,000)$ CFA francs and imprisonment for six (06) months to twelve (12) months:

- failure to comply with the provisions of fisheries management plans;

- violation of the special conditions entered in the fishing license;

- the practice of sea or inland fishing in a prohibited zone or during a prohibited period;

- fishing without authorization or permission in a protected area or in a protected fishing zone;

- fishing, keeping or marketing any species of marine mammal or marine turtles;

- the practice of sea or inland fishing using nets, gear or fishing instruments that are prohibited or do not comply with prescribed standards;

- the use of a prohibited or unauthorized fishing process or method;

- the use for fishing purposes of prohibited materials or substances;

- the transshipment of catches in maritime waters under Beninese jurisdiction;

- the introduction without prior authorization of exogenous aquatic species or genetically modified aquatic organisms into maritime or continental waters under Beninese jurisdiction;

- fishing, transport, purchase or sale of species of aquatic organisms that have not reached the minimum size or weight or for which fishing is prohibited;

- the manufacture, import, possession, purchase or sale of nets, instruments and fishing gear the use of which is prohibited or which do not comply with prescribed standards;

- the creation without prior authorization of an aquaculture establishment or an establishment for the processing of fishery products. 
In addition, the minister in charge of fisheries or the judge may order the suspension of any authorization issued in application of this law for a period not exceeding twelve (12) months.

Article 114: In the event of multiple violations of the provisions of this law and its implementing texts, the most severe penalty is applied.

Article 115: The penalties of fine and imprisonment normally incurred are doubled when:

- $\quad$ There is a recurrence;

- the offense was committed in a protected area or in a protected fishing area;

- the offense relates to a fully protected species of aquatic organism;

- the offense is committed by public officials;

- the offense is committed by the members of a body of water management.

Article 116: There is a repeat offense when, in the two (02) years preceding the commission of the offense, the accused has committed an offense against this law for which he has obtained a transaction or is the subject of a final conviction.

In the event of a repeat offense, the judge orders the license or permit to be withdrawn and deprives the convicted person of the right to obtain it again for a period of two (02) years at most.

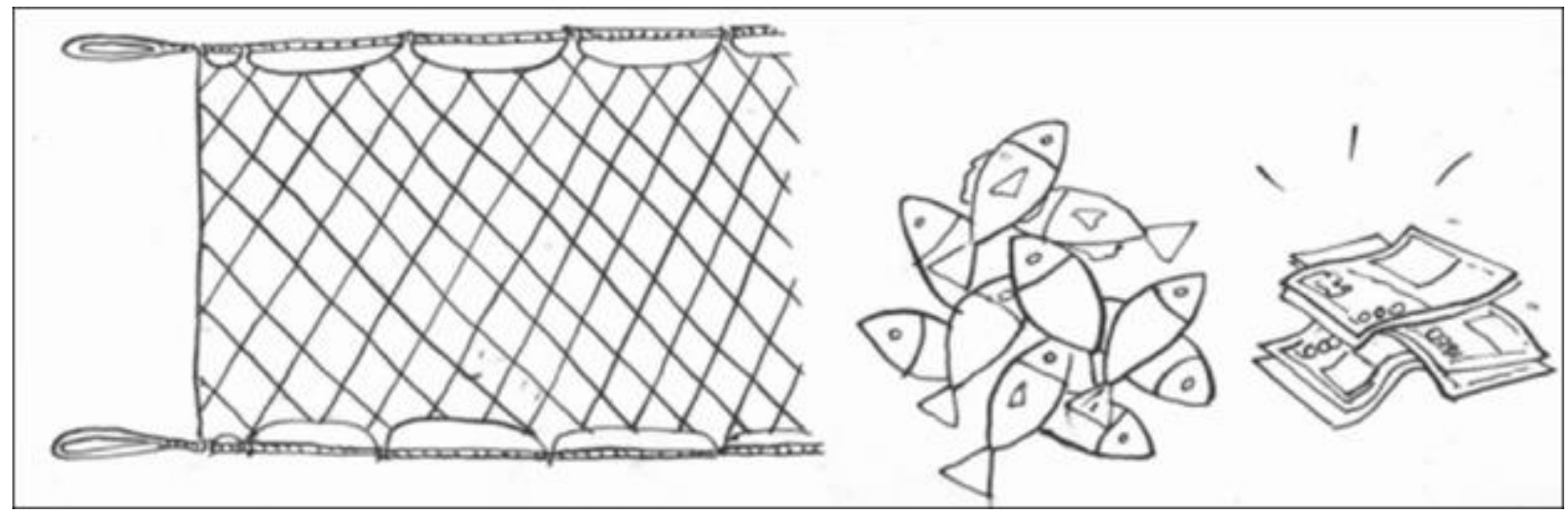

Figure 24 Diagram of a good gillnet

As an illustration, fig 24 shows the diagram of a regulatory mesh gillnet, which catches a small number of large fish specimens with high economic value, while fig 25 shows the diagram of a gillnet with high economic value small mesh which captures a very large number of fish specimens with very low economic value. Fig 24 is therefore an example of sustainable management of aquatic resources [37].

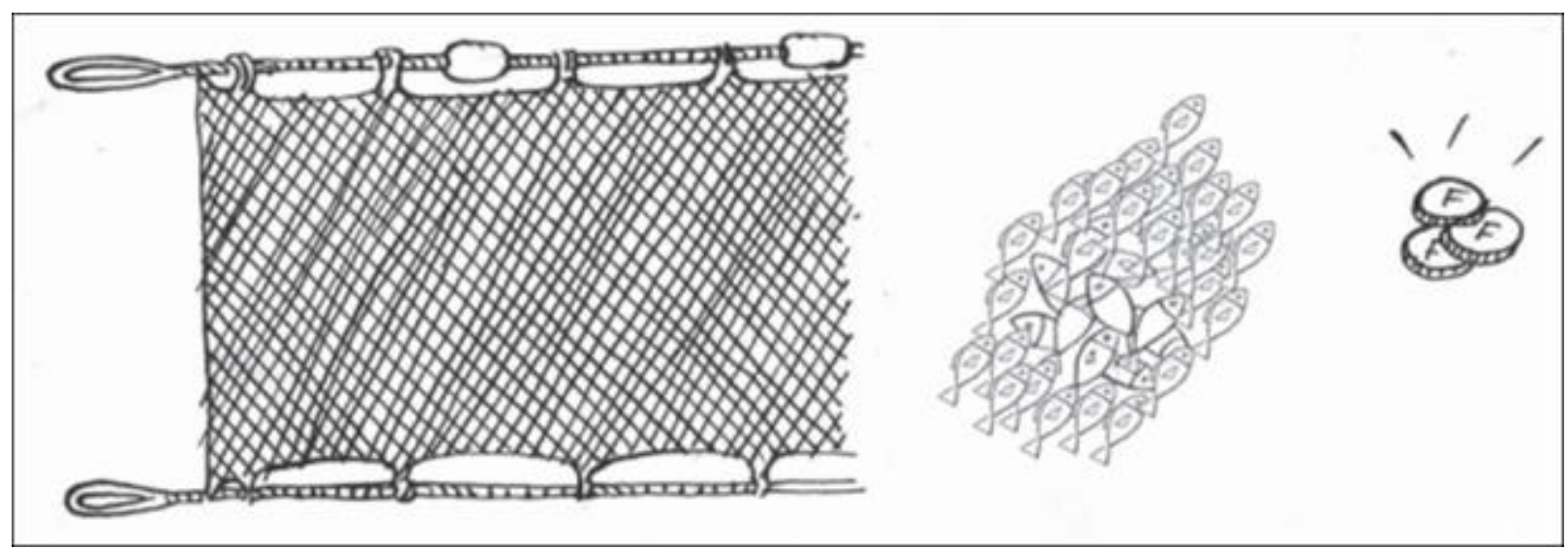

Figure 25 Diagram of a bad gillnet 
In addition, the results show that certain gears and techniques make it possible to capture all the species making up the ichthyofauna in the study area. In fact, out of the 76 recorded species, trap dams (BN), Acadja (AC), hawk nets (FE) and Gbagbaloulou nets (FG), capture $100 \%$ of the species, gillnets (FM) and fishing lines. baited hook longline (PA) catch respectively 97.37 and $82.89 \%$, while fishing using traps (NA) and mosquito nets (MQ) allow fishermen to catch a respective total of 60.53 and $57.89 \%$ of the species, unbaited hook long line (PN) lines and rod lines catch $76.32 \%$ each. These gears represent $75 \%(n=9)$ of the different types of gears inventoried and $81.74 \%$ of the total number of gears counted. These gears and techniques, used in large numbers in the study environment, are devastating to fish species and do not guarantee sustainable management of fishery resources.

\subsubsection{Provisions of the Code of Conduct for Responsible Fisheries (CCPR)}

The objective of the FAO Code of Conduct is to establish international standards of behavior for responsible practices to ensure the effective conservation, management and development of living aquatic resources, while respecting the ecosystem and biodiversity [37, 38].

It has defined principles and international standards of behavior to guarantee responsible practices with a view to effectively ensuring the conservation, management and development of living aquatic resources, while respecting ecosystems and biodiversity. The Code recognizes the nutritional, economic, social, environmental and cultural importance of fishing and the interests of all those affected by this sector. It has taken into consideration the biological characteristics of resources and their environment, as well as the interests of consumers and other users. According to the Code of Conduct for Responsible Fisheries (CCPR), an ideal fishing gear could meet the following criteria:

- be highly selective for target species and sizes, with negligible direct or indirect impact on non-target species and sizes and on habitats (Code of Conduct, paragraphs 7.2.2, 8.4.7 and 8.5.1-8.5. 4);

- be efficient, ie allow large catches of the target species at the lowest possible cost;

- $\quad$ aim for quality, by allowing high quality catches (Code of conduct, paragraph 8.4.4).

- $\quad$ Based on these criteria, and others that we could add to the list, we can easily say that the ideal fishing gear

does not exist in the area of Lake Ahémé and its channels, because no gear meets the criteria. To complete list of desired criteria and properties. However, in the evolution towards a sustainable management of fisheries, the various fishing gears with their specific properties and their possibility of improvement represent an important compartment in "the toolbox of the fisheries manager". It is therefore essential to have some basic knowledge of the properties, role and how to use the main fishing gears and methods to make the necessary decisions in terms of fisheries management, especially when these are technical measures that are found in fisheries regulations.

\subsubsection{Causes of the widespread use of prohibited fishing gear and techniques}

According to the information received from fishermen, the root causes of the widespread use of fishing gear and techniques are stubbornness, the shallow depth of the water bodies and the administrative slowness associated with the issuance of decrees and orders for the application of the framework law on fisheries and aquaculture in the Republic of Benin.

- The stubbornness of fishermen: the fishermen of Lake Ahémé and its channels recognize the importance and the accuracy of the texts in force in terms of fishing in Benin, because not only did they participate in their development through their representatives, but they attended several information and awareness sessions on the content of these texts. However, they oppose their application and persist in the use of prohibited gears and techniques because of the people to be fed. Indeed, demographic pressure is increasing in the study area. People to feed are increasing as the water bodies deteriorate and their area does not increase.

- Shallow water bodies: out of the 14 fishing gear and techniques inventoried in the Lake Ahémé area and its channels, 8 (Acadja, trap dam, Gbagbaloulou conical net, Mindokpokonou net, mosquito net, Ethion net and fishing bamboo and landing net) are used in shallow areas as described. The filling of water bodies is therefore another reason for the use of these fishing gear and techniques in the study area. The Government, by deciding to proceed with the sectorial and partial dredging of these water bodies, will help to solve not only the problem of the use of these prohibited gears which will disappear by themselves, but also will improve the conditions of development of the fishery resources through the improvement of the aquatic ecosystem.

- Administrative slowness in the issuance of implementing decrees for the framework law on fisheries and aquaculture in the Republic of Benin: the promulgation of this law was made by the President of the Republic 
in August 2014. But until 2020 where we were working on the subject, no order implementing this law was available. However, the law has specified that certain implementing provisions, in particular the mesh of the nets, will be fixed by the decrees. Thus, fishermen have been made aware of a law, all of the implementing provisions of which do not yet exist. This created a legal vacuum which the fishermen exploited, continuing to use the prohibited gear.

In short, the fishing gear and techniques used by the fishermen of Lake Ahémé and its channels do not ensure rational and sustainable management of fishery resources. Some contribute to the degradation of the aquatic ecosystem through the filling and congestion of water bodies, others lead to the destruction or even disappearance of species, others cause the loss of plant cover in the immediate environment, and finally, others are very dangerous for humans.

Faced with this situation, the water bodies need to be cleaned up. Thus, the Government of the Republic of Benin has decided to clean up these water bodies through the systematic removal of fishing gear and techniques prohibited by law and the texts in force.

\subsubsection{Operations for the removal of prohibited fishing gear and techniques on Lake Ahémé and its channels}

Despite the existence of this legal arsenal in Benin and in the CCPR of which Benin is a stakeholder, we have observed that the water bodies are taken over by prohibited fishing gear and techniques. Faced with this situation, the Government decided to clean up the water bodies through the systematic removal of prohibited devices and techniques. Thus, after several awareness-raising and information sessions for both the structures involved (the Defense and Security Forces: Naval Forces, Republican Police, River Police, Water, Forests and Hunts, Firefighters; the Judiciary: Presidents of the Courts, district Attorney; prefects), (fig 26), and grassroots populations (mayors and municipal councils, district and village councils and socio-professional organizations of fishermen). These sessions were cofacilitated by the Fisheries Production Department and the Agency for the Integrated Development of the Economic Zone of Lake Ahémé and its Channels (ADELAC). These sessions enabled a massive adherence of fishermen to the activities and ensured a smooth execution of the sanitation missions. After raising the awareness of the various actors involved, the actual operations began with the preparation of the teams fig 27), followed by the removal of prohibited gears and techniques (fig 28 to 30). The removed branches are transported to the bank using motorized boats. The nets removed are transported and incinerated on a site selected for this purpose (fig 31). As for the Acadja branches, they are cremated on the banks of bodies of water, far from homes (fig 32).

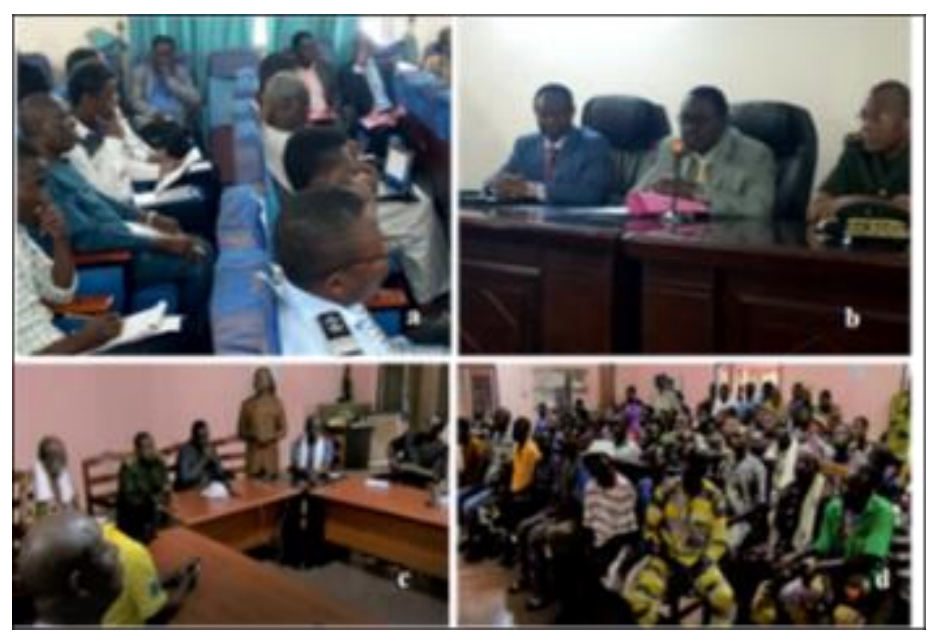

Figure $26 \mathrm{a}$ and b) Information of the heads of structures by the Minister of Agriculture, Livestock and Fisheries; $\mathrm{c}$ and d) Sensitization of the populations living around Lake Ahémé, of the Mayors and Development Associations of the municipalities of Bopa and Comé 


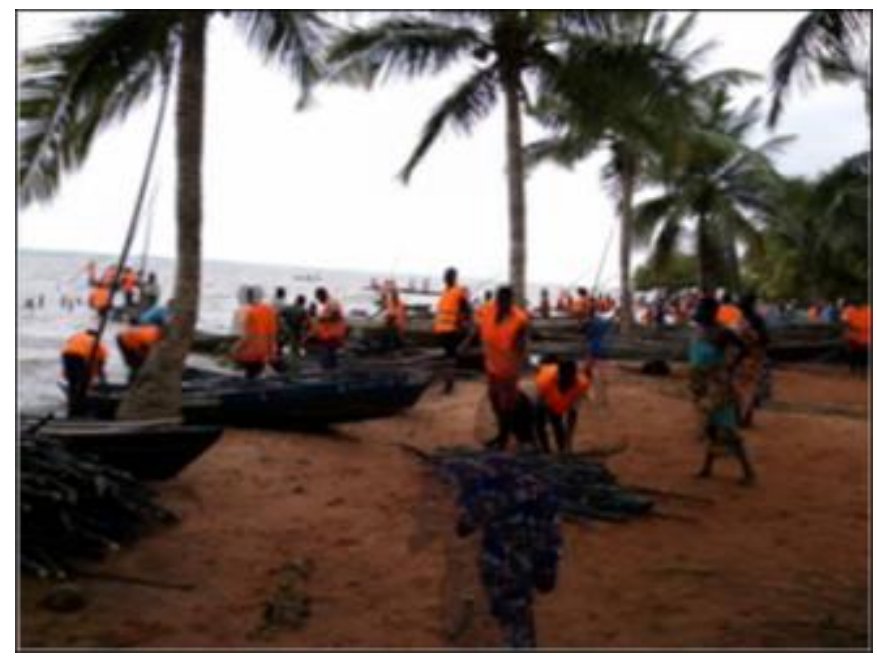

Figure 27 Preparation of teams to clean up the acadjas on Lake Ahémé

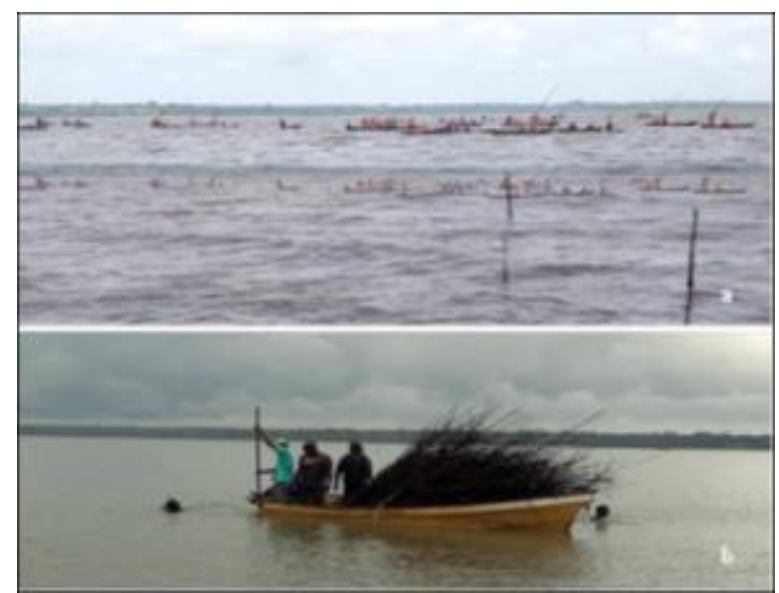

Figure 28 a) Movement of fishermen in canoes, towed by a motorized boat to the places of operation; b) Divers in the middle of loading a motorized boat with the acadjas removed from Lake Ahémé

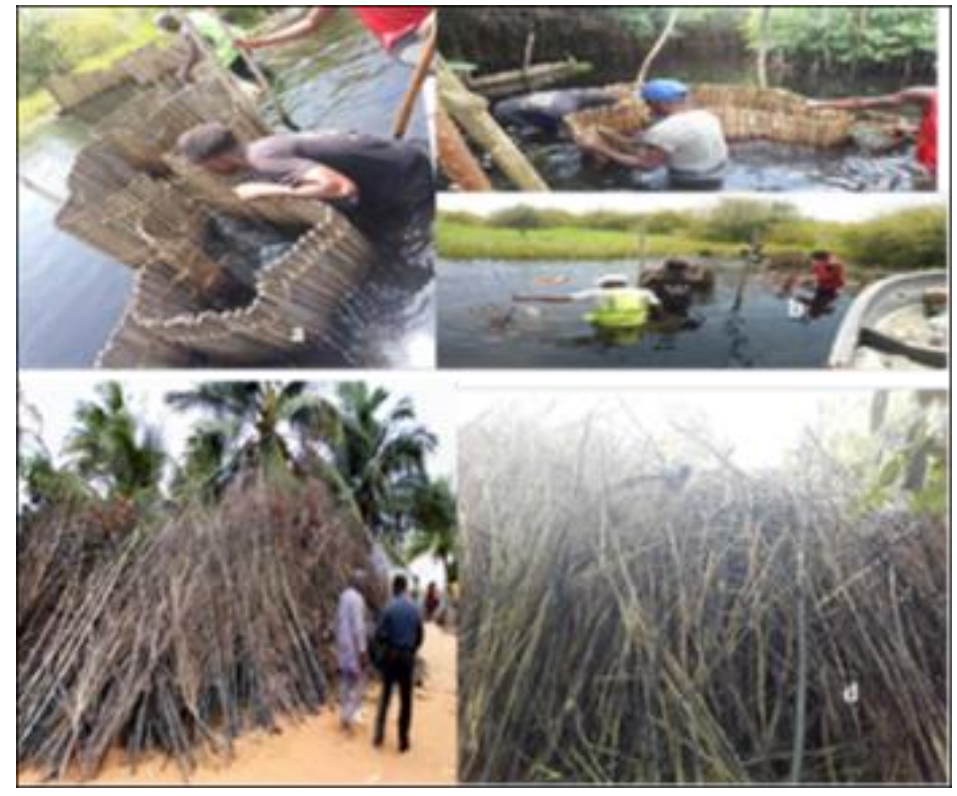

Figure $29 \mathrm{a}$ and b) Fishermen in the midst of dismantling of the xha trap dams, in the channels; c and d) Acadja parks removed from Lake Ahémé at village level Vonvio, Municipality of Kpomassè 


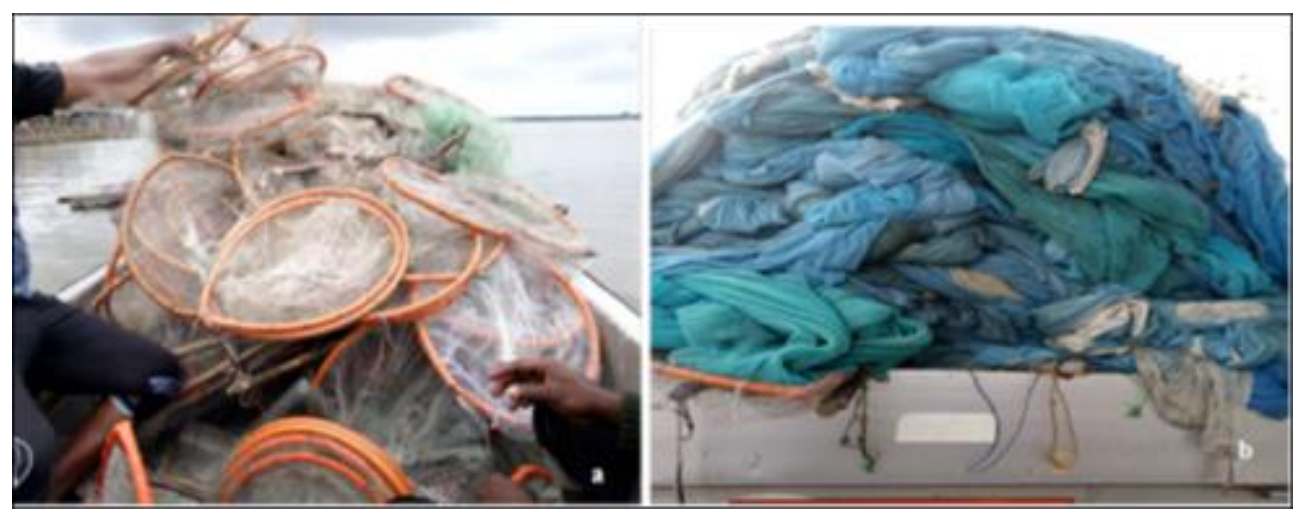

Figure 30 a) Gbagbaloulou fixed nets removed from Lake Ahémé in Guézin, Commune of Comè; b) Mosquito nets removed from Lake Ahémé loaded into a van to be transported to the incineration site in Comè
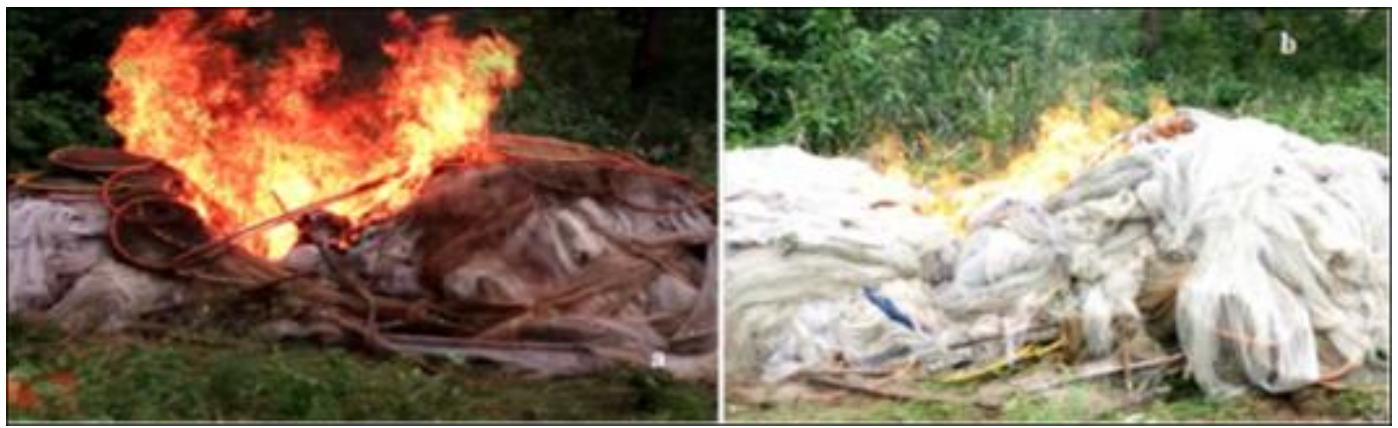

Figure 31 Gbagbaloulou Fixed Nets being incinerated on the CARDER Comè site

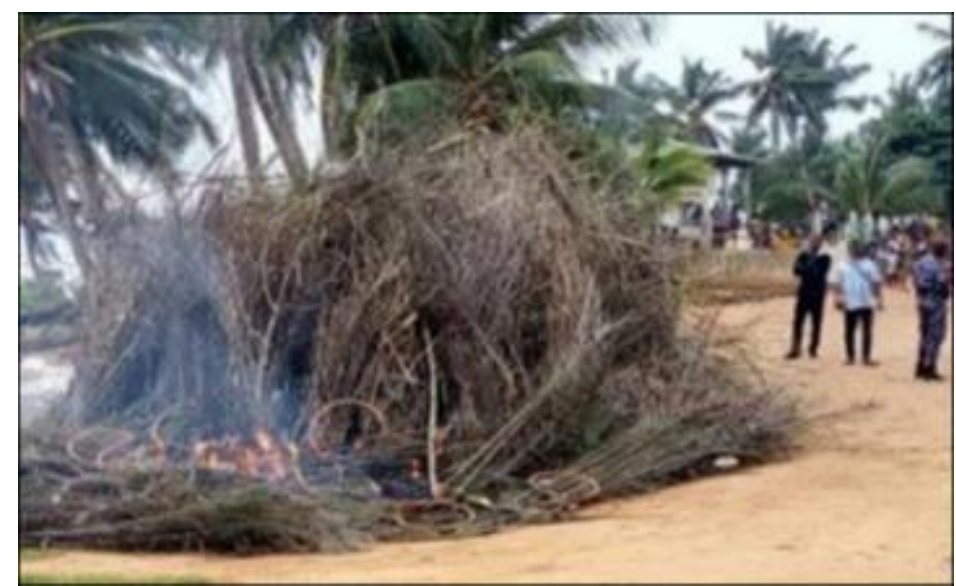

Figure 32 Acadja Park being incinerated on the shore of Lake Ahémé in Possotomè

\subsection{Support measure for fishermen after the sanitation of water bodies}

After the sanitation of the water bodies, the Government, through the Agency for the Integrated Development of the Economic Zone of Lake Ahémé and its channels, opted for the diversification of activities and sources of income for fishermen. Thus, from December 2019 to May 2020, more than 500 fishermen were trained in snail breeding in the area of Lake Ahémé and its channels. For the pilot phase of the project, 200 trained fishermen benefited from a support known as a " snail breeding kit". Each kit consists of 50 brood snails, $20 \mathrm{~kg}$ of feed and an enclosure for starting the activity (fig 33 and 34). 


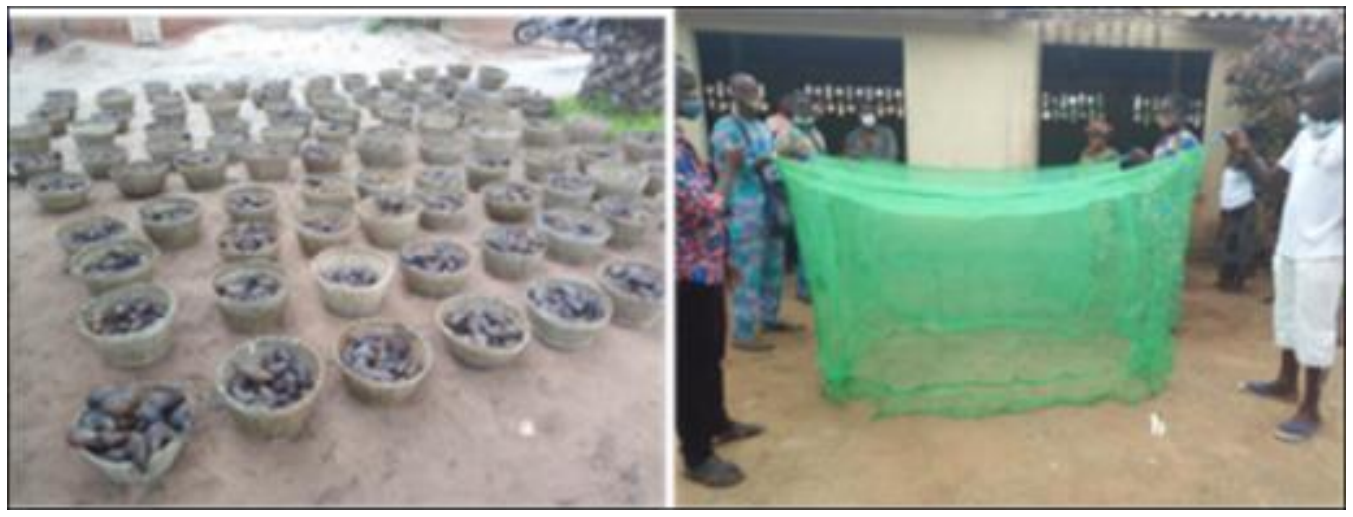

Figure 33 a) Baskets containing brood snails; b) Snail breeding enclosure

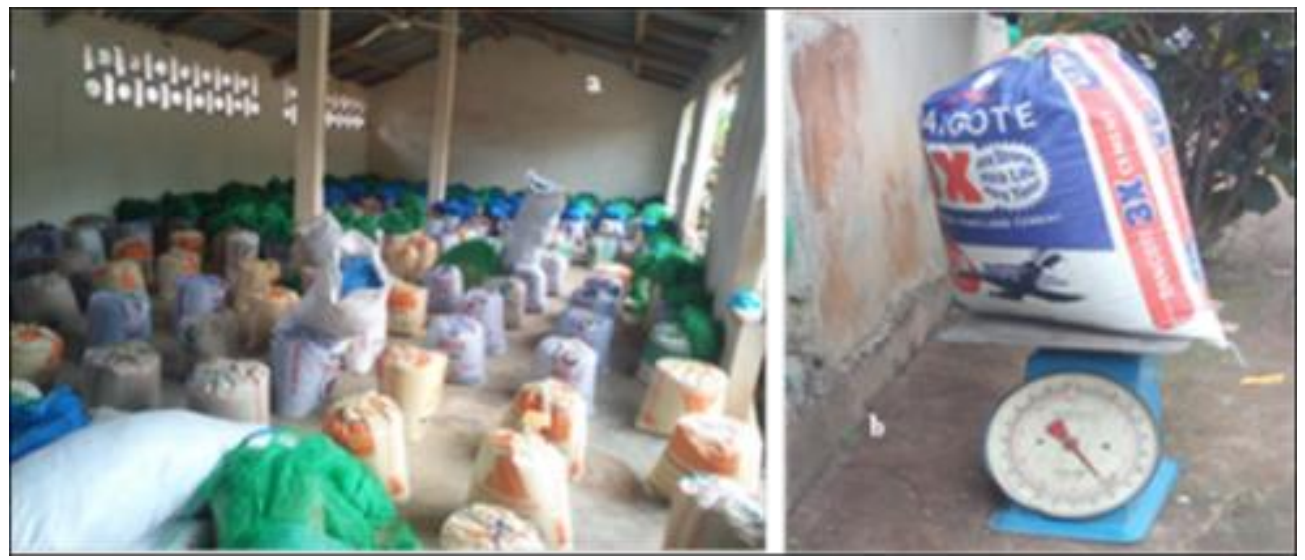

Figure 34 a) Bags containing $20 \mathrm{~kg}$ of snail feed; b) Weighing of a bag containing $20 \mathrm{~kg}$ of feed

\section{Conclusion}

The fishing gear and techniques inventoried on Lake Ahémé and its channels during the study period include nets, lines, pots, Acadjas and trap dams (Xhas), categorized into 12 gear and 02 techniques. These devices and techniques have been described. Analysis of the results shows that $86 \%(n=12)$ of the gears are constant. None of the devices and techniques are accidental or rare and $14 \%(n=2)$ of the devices are incidental. The machines vary according to the bodies of water and the stations. The conical Gbagbaloulou nets numerically dominate the gear (16.48\%) while the landing net, located only at the level of the stations of LA1 and LA2 is the least represented (0.16\%). The smallest mesh measured during the study period is $2 \mathrm{~mm}$ (Ethion net), while the largest mesh is $25 \mathrm{~mm}$ (gillnets and hawk). The functioning of fishing gear and techniques shows that some contribute to the degradation of the ecosystem and others act on resources. In light of the measures for the conservation of fishery resources and aquatic ecosystems contained in FRAMEWORK LAW $N^{\circ}$ 2014-19 OF AUGUST 07, 2014 relating to fishing and aquaculture in the Republic of Benin, certain gear and techniques are prohibited. With the exception of hawk, Ethion, landing net and gill nets with mesh size greater than $20 \mathrm{~mm}$, as well as hook lines and baited hook long lines, all other gear and techniques are prohibited by law. However, the law enforcement orders have not yet been made and the shallow depth of the water bodies lead fishermen to continue the bad practices. In view of the nuisance caused by fishing gear and techniques both on resources and on the environment, the Government has cleaned up the water bodies through the systematic removal of these gear.

\section{Compliance with ethical standards:}

\section{Acknowledgments}

- Fishermen living on Lake Ahémé and its channels

- Agency for the Integrated Development of the Economic Zone of Lake Ahémé and its Channels 
- Department of Fisheries Production

\section{Disclosure of conflict of interest}

The authors declare that they have no competing interests

\section{Statement of informed consent}

This study is not concerned with obtaining informed consent from participants

\section{References}

[1] D ADANDEDJAN. 2012, "Diversity and determinism of populations of benthic macrovertebrates in two lagoons in southern Benin: the Porto-Novo lagoon and the coastal lagoon" Unique Doctorate in Agronomic Sciences from the University of Abomey-Calavi. 2012; 239.

[2] ADITÉ A. The mangrove fishes in the Benin estuarine system (Benin, West Africa): diversity degradation and management implications. Actes de la conférence, The Second Large Rivers Symposium, 11 -14 Février 2003, Phnom-Penh, Cambodge. 2003; 25.

[3] D ADANDEDJAN, TM AGBLONON HOUELOME, S AHOUANSOU MONTCHO, S HOUNKPE, P LALEYE. "Antropogenic impacts on water quality and macroinvertebrates distribution of Toho Lake, South West Benin" Journal of Biodiversity and Environmental Sciences. 2018; 13(6): 152-165.

[4] A BADAHOUI, ED FIOGBE, M BOKO. The causes of the degradation of Lake Ahémé and its channels. URZH / DZG / FST / UAC, EDP / FLASH / UAC, 01 BP 526 Cotonou, Benin, Available online at http://ajol.info/index.php/ijbcs, Int.J. Biol. Chem.Sci. August 2010; 4(4): 882 - 897.

[5] C HOUNKPE. 1996. Current situation of controversial fishing methods. Study report. 1996; 26.

[6] P LALÈYÈ, C NIYONKURU, J MOREAU, GG. TEUGELS, 2003. "Spatial and seasonal distribution of the ichthyofauna of Lake Nokoué, Bénin, Ouest Africa". In African Journal of Aquatic Science. 2003; 28(2): 151 - 161.

[7] ALBARET, 1994. Fish: Biology and populations, p 239-273. In J.-R. Durand et al., (Eds.), Environment and aquatic resources of Côte d'Ivoire. Volume II - The lagoon environments. 1994.

[8] T MURAI, JB DEGBEY, C HOUNKPE ET, J METOGNINOU. Atlas of fish and shellfish from fresh and brackish waters of Benin. 2003; 46.

[9] F GNIDETE, CS HOUSSOU M GIBIGAYE, EW VISSIN, P CLEDJO, P LALEYE. 2017 : Devastating fishing systems for natural resources in the Couffo-Ahémé-Ahô-coastal lagoon river-lake complex, South-West Benin Rev. Ivory. Sci. Technol. 2017; 30: 160 - 181

[10] AMOUSSOU E. 2003. Hydro-sedimentary dynamics and changes in the ecosystems of Lake Ahémé. Master's thesis, DGAT / FLASH / UAC. 2003; 103.

[11] J HODIGUE. 2012. Environmental impacts of fishing activities in southern Benin. Single Doctorate Thesis, EPD / FLASH / UAC. 2012; 230.

[12] D ADANDEDJAN, TM AGBLONON HOUELOME, S AHOUANSOU MONTCHO, S HOUNKPE, P LALEYE. Antropogenic impacts on water quality and macroinvertebrates distribution of Toho Lake, South West Benin Journal of Biodiversity and Environmental Sciences. 2018; 13(6): 152-165.

[13] CC VIAHO. 2014. Inventory of the ichthyological fauna of Lake Ahémé and its channels and some bioecological aspects of the dominant species. Master's thesis, University of Abomey-Calavi, Benin. 2014; 94.

[14] E AMOUSSOU 2014. Ancient lakes and lagoons in South-West Benin, inventory of IUCN Benin Study report. 2014; $122-201$.

[15] LALEYE PA. 2000. National Monograph of Biological Diversity. The aquatic ecosystems of Benin: Inventory and status. 28p. University of Abomey-Calavi. Benign. 2000.

[16] PNE-BENIN. 2010 Technical note on the challenges and strategic orientations for the management of conflicts related to fishing gear and techniques on Lake Ahémé and the Lake Nokoué-Lagune complex in Porto-novo. 2010; 21p. 
[17] INSAE, 2016. Number of the population of villages and city districts of Benin. RGPH-4, 2013, Cotonou, February. 2016; 85p.

[18] KS KONAN, KL KOUASSI, KF KONAN, KL KOUAME, K AKA, D GNAKRI. 2013. Evaluation of solid loads and hydrochemical characterization of the waters of the Ayamé 1 hydroelectric dam lake (Ivory Coast). Bulletin of the Scientific Institute, Rabat, Earth Sciences Section. 2013; (35):17-25.

[19] AHOUANSOU MONTCHO. S. 2011. Diversity and Exploitation of Fish from the Pendjari River (Benin, West Africa) THESIS FROM THE GRADE OF DOCTOR OF THE UNIVERSITY OF ABOMEY-CALAVI. 2011; 235.

[20] C LEVEQUE, D PAUGY. 1999. Settlement of rivers and associated biotopes. In: Fish from African inland waters: Diversity, ecology, human use, IRD (Eds),Paris. 1999; 283-294.

[21] C LEVEQUE, D PAUGY, GG TEUGELS. 1990. Fauna of the fresh and brackish water fish of West Africa. Volume 1 Edition of ORSTOM. Royal Museum for Central Africa Tervuren, Belgium. Tropical Fauna Collection $n^{\circ}$ XXVIII. $1990 ; 384$.

[22] DAJOZ R. 2000. Precise ecology. 7th Edition. Dunod, Paris. 2000; 615.

[23] J PLIYA. 1981. Fishing in the South-West of Benin (Geography study applied to inland and sea fishing). Cultural and Technical Cooperation Agency, Paris. 1981; 296.

[24] A FAYE, M DIOUF, A SARR, W NDIAYE, A MBODJ, N LAZAR. 2018. Gillnet Selectivity for Ethmalosa fimbriata in Saloum Delta and Joal (Senegal) 2018: Turkish Journal of Fisheries and Aquatic Sciences. 2018; 18: 761-769.

[25] AH ATTINGLI, S AHOUANSOU MONTCHO, EW VISSIN, LH ZINSOU, PA LALEYE. 2017. INFLUENCE OF FISHING GEAR AND TECHNIQUES ON THE RELATIVE ABUNDANCE OF SPECIES IN THE LOWER OUEME VALLEY OF BENIN African Crop Science Journal. 2017; 25(1): 47 - 70.

[26] B AGBANDOU, D HOUESSOU, F THOTO, G CHABI. 2018. Ecosystem imbalance of the Lake Nokoué lagoon complex - Porto-Novo lagoon: What can be done to avoid ecological disaster and protect the health of the populations of Benin? ACED NGO Policy Note https://www.aced-benin.org/fr/publications. 2018.

[27] ACP FshII 2011. Final technical report: Formulation of a sectoral policy document on fishing and aquaculture in Togo 58p + annexes. 2011.

[28] Ibrahim ADO MOUSSA. 2018. Influence of fishing on the structure of fish stocks in the fisheries of Boubon in Niger: MORAP Master's thesis, University of Abomey-Calavi. 2018; 99.

[29] Yves GAUTHIER, Christine GAUTHIER 2016: Men and Lakes Population of lake areas from Borkou (Chad) to the Holocene in Lake Chad. Sahelian wetlands challenged by global change.

[30] Yves FERMON 2007. Study of the state of play of the northern part of Lake Tanganyika within the framework of the Fishing Action Against Hunger program in the Democratic Republic of Congo Mission report. 2007; 86.

[31] T BOUSSO. 2004. TYPOLOGY OF ARTISANAL FISHING GEAR AND TECHNIQUES USED IN SINE-SALOUM (SENEGAL) Scientific document (14) (1) (2004) from the Dakar Oceanographic Research Center. 2004; 111.

[32] A BADAHOUI, ED FIOGBE, M BOKO. 2009. The causes of the degradation of the Cotonou channel. Int. J. Biol. Chem. Sci. October 2009; 3 (5): 979-997.

[33] C NIYONKURU, P LALEYE, C HOUNKPE, J MOREAU. 2003. Impact of fishing on the aquatic resources of the water bodies of southern Benin. In: Third International Conference of the Pan-African Fisheries Association. Benign. 2003; 193 - 194.

[34] Villéger S, Ramos Miranda J, Flores Hernández D, Mouillot D. 2010. Contrasting changes in taxonomic vs. functional diversity of tropical fish communities after habitat degradation. Ecological Applications: A Publication of the Ecological Society of America. 2010; 20(6): 1512-22.

[35] CC VIAHO. 2020. Physico-chemical characterization of Lake Ahémé and its channels in southwestern Benin Afrique SCIENCE. 2020; 17(4): 72 - 92.

[36] FAO. 2011; Code of conduct for responsible fishing Report ISBN 978-92-5-206708-5.

[37] DPH. 2014. FRAMEWORK LAW N ${ }^{\circ} 2014-19$ OF AUGUST 07, 2014 relating to fishing and aquaculture in the Republic of Benin. 2014.

[38] ADEFIH 2011. Support for the Development of Fisheries Sectors in Benin DEFIH, Benin, final report of the project. 2011; 104p. 